\title{
NEGATION AND LEXICAL MORPHOLOGY ACROSS LANGUAGES: INSIGHTS FROM A TRILINGUAL TRANSLATION CORPUS
}

\author{
BRUNO CARTONI \\ Université de Genève \\ bruno.cartoni@unige.ch \\ MARIE-AUDE LEFER \\ Université catholique de Louvain and Institut libre Marie Haps \\ marie-aude.lefer@uclouvain.be
}

\begin{abstract}
This paper proposes an exploratory cross-linguistic bird's eye-view of negative lexical morphology by examining English, French and Italian negative derivational affixes. More specifically, it aims to uncover the French and Italian equivalents of the English affixes de, dis, in, non, un and less. These include morphological equivalents (i.e. negative prefixes in French and Italian) as well as non-morphological equivalents (i.e. single words devoid of negative affixation, multi-word units or paraphrases). The study relies on a nine-million-word trilingual translation corpus made up of texts from the Europarl corpus and shows that the systematic analysis of translation data makes it possible to identify the major morphological dissimilarities between the three languages investigated. The frequent use of non-morphological translations in French and Italian reflects fundamental differences between the source language (English) and the two target languages (French and Italian), hence pointing to possible translation difficulties. Morphological translations, on the other hand, bring to light cross-linguistic similarities in the use of negative affixes.
\end{abstract}

KEYWORDS: Lexical morphology; derivation; negation; multilingual corpora; translation.

\section{Introduction}

Negation has traditionally been described as a linguistic operation used to turn a positive statement into a negative one. It can often be expressed both syntacti- 
cally by means of negative adverbs (and to a lesser extent adjectives) and lexically through word-formation processes. Many languages include a negative morphology, i.e. a set of morphological processes that can be used to coin negative lexemes with a range of different sub-meanings. The number and type of processes used in negative morphology, however, greatly differ crosslinguistically.

This paper presents a corpus-based study of negative morphology in three languages, viz. English, Italian and French, and specifically focuses on the French and Italian translation equivalents of English negative affixes. The contrastive study of lexical morphology is a recent endeavour. Contrastive studies to date have mainly focused on other levels of linguistic description (such as phonology and grammar in their early days and, more recently with the advent of corpus linguistics, on lexicology), with morphology clearly standing out as the parent pauvre of contrastive linguistics (Lefer and Cartoni 2011; Lefer, this volume). However, contrastive analysis can be used to get new insights into linguistic phenomena that would not have been brought to light without the crosslinguistic magnifying glass. Moreover, the findings of contrastive morphology can prove to be very useful in various fields, such as monolingual and multilingual lexicography, translator training and second-language learning and teaching.

In this study, we rely on a nine-million-word translation corpus. Corpusbased contrastive analyses can be carried out on the basis of two types of electronic corpora: comparable corpora and translation corpora. Comparable corpora consist of original texts in two or more languages matched by criteria such as register, genre, domain, time of publication, size, etc. Translation corpora, by contrast, consist of original texts and their translations into one or several languages. The two types of corpora each display strengths and weaknesses and have often been considered as complementary resources (see Granger 2003; Johansson 2007). When using translation corpora, it is particularly important to bear in mind phenomena such as translationese (i.e. source text interference; see Gellerstam 1996), translation-specific features (e.g. possible translation universals; see Baker 1993 and Laviosa 2002) and outright translation errors, all of which are yet to be further explored. These limitations notwithstanding, translation corpora offer invaluable repertories of cross-linguistic equivalents.

The article is structured as follows. Section 2 describes the overall objectives of the present study and Section 3 presents the different sub-meanings of morphological negation (opposition, reversal and removal, contradiction, privation and contrary) and the categories of lexemes involved in each sub-meaning. 
Section 4 introduces the empirical data that were used to carry out the contrastive analysis as well as the data extraction method. Sections 5 and 6 discuss the results of the contrastive analysis. The article ends with some concluding remarks in Section 7.

\section{Objectives}

As explained from the outset, our study proposes an exploratory cross-linguistic bird's eye-view of negative morphology. More specifically, it aims to uncover the French and Italian equivalents of English negative affixes. These include morphological equivalents (negative prefixes) as well as non-morphological equivalents (lexical and syntactic negation).

Our starting-point assumption is that the systematic analysis of translation data extracted from corpora can empirically bring to the fore the major morphological dissimilarities between English, French and Italian. More specifically, our research question is two-fold:

- Are well-known differences between the source language (English) and the target languages (French and Italian) reflected in the frequent use of nonmorphological translations (i.e. translations into single words or paraphrases)? Can other (unexpected) contrasts be unearthed thanks to the translation corpus approach?

- Can the systematic analysis of two target languages (Italian and French) bring to light (some of) their major areas of similarity and difference?

Our study is thus doubly contrastive, as the source language is compared to the target languages and the target languages are compared to each other. Common features displayed by the two target languages may be regarded as good indications of cross-linguistic contrasts between English and the two Romance languages investigated here.

As stated above, the study presented here aims to provide data-driven general descriptions of the similarities and differences between negative affixes in three languages and thereby refine the patchy descriptions found in the reference literature. In doing so, we hope to identify future paths for contrastive morphological research and formulate first generalisations on the use and translation of negative affixes in English, French and Italian. Our ultimate objective is to feed an existing lexicographic resource, which aims to present wordformation processes in a multilingual database designed for both language spe- 
cialists (e.g. linguists, terminologists, lexicographers, Natural Language Processing specialists) and second-language learners and trainee translators (Cartoni and Lefer 2010). It is currently under development and accessible online. ${ }^{1}$

\section{Morphological negation}

A range of word-formation processes can be used to coin negative meanings (in the broadest sense of the word). These processes include prefixation (e.g. unhappy), suffixation (e.g. powerless), compounding (e.g. sugar-free) and conversion (e.g. to dust 'to remove the dust'). In the languages under examination in this paper, negative morphology is chiefly conveyed by means of affixation (especially prefixes). Semantically, negative morphology can be classified into five sub-categories. They are described in Section 3.1. English, French and Italian negative affixes are then presented in Section 3.2. The section ends with some preliminary observations (Section 3.3).

\subsection{The five sub-categories of negation}

Negative affixation can be subdivided into five categories which denote the relation that holds between the derivative and its base (see Hamawand 2009; Iacobini 2004; Montermini 2002): contradictory negation, contrary negation, privation, reversal and removal, and opposition. This section briefly deals with each of these categories in turn.

Contradictory affixes "exhaust the possibilities along a given dimension" (Zimmer 1964: 21). The contradiction of one end of the dimension necessarily imposes the affirmation of the other, with no in-between (e.g. non-American qualifies someone or something that is not American). Contradictory negation is said to be neutral, impartial in tone, descriptive and unemotional, i.e. it does not usually convey negative evaluation.

Contrary negation, by contrast, leaves some room for other possibilities between the two ends of the scale (e.g. un-American can be defined as 'not in consonance with American characteristics; contrary to the ideals and interests of the United States of America', OED-online) (Zimmer 1964: 21). Contrary negation is mainly found in adjectives (e.g. happy - unhappy) and can be used to express evaluation (Zimmer 1964; Funk 1971; Algeo 1971), i.e. it is often used in a de-

\footnotetext{
${ }^{1}$ See $<$ https://sites.google.com/site/mulexfor/> (last accessed 1 April 2011).
} 
preciative sense to convey unfavourable judgment. According to Lieber (2004), negative prefixes may express a contradictory or contrary meaning, depending on the meaning of their base. Scalar or gradable adjectives, such as happy or violent, can give rise to the contrary interpretation (also referred to as antonymy by Lyons 1968) while non-gradable adjectives necessarily give rise to contradictory meanings.

Privative negation expresses the lack of the entity or action denoted by the base, which can be a noun or a denominal verb (e.g. disorder is the lack of order) while reversal and removal involve the return to an original state or the removal of the entity denoted by the base. In the reversative meaning, the affixation process generally involves a verbal base (to undo is the process of reversing the doing), and can consequently apply to deverbal nouns or deverbal adjectives. The removal affixation process applies to nominal bases to coin verbs with the meaning of 'removing the entity denoted by the base noun'. The boundary between removal and reversal is not always clear-cut (e.g. disarm can be interpreted as 'taking away someone's weapons' or 'reducing the number of weapons in an army').

Opposition affixes are sometimes also included in the group of negative affixes. They express the antagonistic relations between the derivative and its base (e.g. antimatter, anti-Bush). The prototypical prefix widely used in the three considered languages is anti $^{2}$ (and, to some extent, Fr. contre / It. contro / En. counter). This prefix is highly productive in the three languages.

This study focuses on contradictory, contrary, privative and reversal/removal affixes. Affixes conveying opposition will not be investigated here, as they are not systematically classified as straightforward members of the category of negative affixes in the reference literature (cf. Plag 2003: 99, where anti is considered as a "close relative" of negative affixes but not as a negative affix as such).

The boundaries between the five categories are very fuzzy, notably because some affixes can convey more than one negative sub-meaning. While the opposition category seems rather clear-cut, the situation is far more complex for the other categories. A notable example is the English prefix un, which can express contrary and contradictory negation as well as reversal and removal (see Section 3.2).

\footnotetext{
${ }^{2}$ Hyphens are not used to represent affixes in this paper (cf. the discussion of the use of the hyphen with the prefix non below).
} 
The phenomenon of affix rivalry should also be mentioned. For example, there are many contradictory-contrary pairs in English. Some of them are mentioned in (1) (Funk 1971: 378):

(1) inactive - non-active

$$
\begin{aligned}
& \text { incompetent - non-competent } \\
& \text { ineffective - non-effective } \\
& \text { unrepresentative - non-representative } \\
& \text { unspecific - non-specific } \\
& \text { untypical - non-typical } \\
& \text { involuntary - non-voluntary }
\end{aligned}
$$

As regards these pairs, Funk (1971: 379) underlines that "the non-derivative aims at (more or less formal) classification, while the $u n$-/in-derivative aims at (more or less essential) characterization or judgement" (see Gaatone 1971: 21 for similar comments regarding the French non and in).

\subsection{Overview of negative affixes in English, French and Italian}

Following the three-step contrastive methodology advocated in Lefer and Cartoni (2011), namely description, juxtaposition (here on the basis of a semantic tertium comparationis, viz. negation) and comparison, the affixes under study first need to be described from a purely monolingual perspective. The descriptions that follow are based on various studies devoted to English, French and Italian morphology. However, an exhaustive comparison based exclusively on the literature is rather difficult to make as the literature itself offers diverging overviews of negative affixation. This provides a strong argument for empirically-based contrastive research, which will hopefully go some way towards clarifying or refining the descriptions of negative affixes in the three languages investigated.

\subsubsection{English}

English relies on six prefixes (a, de, dis, in, non, un) and one suffix (less) to coin negative meanings derivationally. Etymologically speaking, un and less are 
Germanic affixes while $a$, de, dis, in and non are Romance affixes. Even though etymological information is rarely a valid criterion to characterise word-formation processes synchronically, the distinction between the two English stocks of affixes has to be borne in mind. The introductory overview provided here is mainly based on Bauer (1983), Plag (2003) and Lieber (2005). The reader is referred to Zimmer (1964) for further details.

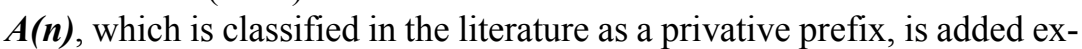
clusively to Latinate adjectives. In denominal adjectives, its meaning can be paraphrased as 'without what is referred to by the nominal base', as in asexual 'without sex', or as 'not X', as in asymmetrical (Plag 2003: 99). It can be considered as marginally productive (Bauer 1983: 218). Lieber (2005), for example, does not include $a$ in her discussion of English negative prefixes.

$\boldsymbol{D} \boldsymbol{e}$ attaches to verbs and nouns to form reversal and removal verbs, which are frequently nominalised or adjectivalised. Examples include deselect and decolonise. It is in competition with dis and un, which can also be used to form verbs, and specifically favours verbs suffixed in ise, ate and ify. It is not used to form adjectives.

Dis forms reversative verbs with Latinate verbal bases (e.g. disconnect) and verbs meaning 'not V' (e.g. disagree 'not agree'), a feature that it does not share with its rivals $d e$ and $u n$. Dis can also be prefixed to nouns, where it means 'absence of N' or 'faulty N' (e.g. disinformation), and to adjectives, with the meaning 'not A', as in dishonest. However, this last use is not productive (Plag 2003: 100).

In mainly attaches to Latinate adjectives where it conveys the meaning of 'not A' (e.g. inactive). According to Bauer (1983: 219), it does not appear to be productive in English, mainly because of its productive rival $u$ and because of the existence of other productive in prefixes (e.g. in-house). Lieber (2005: 391), however, notes that in productively attaches to adjectival bases.

Non, which also attaches to adjectives, means 'not A' (e.g. noncommercial). It is different from in and $u n$ in that it mainly conveys contradiction and is devoid of evaluative force. Non also attaches to nouns, with the meanings of 'absence of N' or 'not having the character of N', as in nondelivery, non-member. Furthermore, it has developed the meaning of 'being $\mathrm{N}$, but not having the proper characteristics of an N' (e.g. non-answer) (Plag 2003: 101):

(2) However, the same phrase may also apply to the Australian government and its hitherto secure private thoughts and secret actions if this week's 
WikiLeaks revelations - or non-revelations - are any indication. (Brisbane Times, 2 December 2010)

$\boldsymbol{U} \boldsymbol{n}$ can be used to form reversal and removal verbs on the basis of verbal or nominal bases (e.g. uncork, unwrap). It especially favours causative/inchoative verbs which imply a result that is not permanent (Lieber 2005: 393). It is also used to form negated adjectives (both on the basis of simple and complex adjectives), where it mainly conveys contrary negation (especially with morphologically simple bases, e.g. unclear). Finally, un sometimes attaches to nouns with the meaning of 'absence of N', as in unbelief.

Less, which is used to form denominal adjectives, can be paraphrased as 'without N', as in expressionless, speechless. It is often described as a privative suffix. It is no longer productive when added to verbs (e.g. countless) (Bauer 1983: 224) and has no direct equivalent in the Romance languages.

\subsubsection{French}

French only resorts to prefixes to coin negative lexemes (a, dé(s), dis, in, non). To our knowledge, no extensive empirical study has yet provided a general overview of French negative prefixation, ${ }^{3}$ although several studies (most of them carried out within the generative framework) have discussed two prefixes in some depth, namely in (Tranel 1976; Apothéloz 2003; Schwarze 2004, 2005) and dé (Gary-Prieur 1976; Boons 1984; Muller 1990; Amiot 2008).

In French, the prefix non only applies to nominal bases and is always hyphenated. According to (prescriptive) grammars such as Grevisse (1993), non can be considered as a prefix in front of nouns (and is consequently graphically related to the base by means of a hyphen) and should be considered as an adverb in front of adjectives (and consequently detached from the base). However, this norm does not seem to be strictly followed. The Trésor de la Langue Française informatisé (TLFi) dictionary (Imbs et al. 2004) notes that, while the hyphen is almost systematic with nominal bases, its use is quite unsettled in front of adjectives.

The prefixes in and $\boldsymbol{a}$ mainly attach to adjectives (and deadjectival nouns) and chiefly convey contrary negation. Huot (2007) underlines the preference of

\footnotetext{
${ }^{3}$ A dictionary-based description is presented in Gaatone (1971).
} 
the prefix in for adjectival bases, and adds that, when prefixed to a past participle, it applies to its adjectival value. In also seems to favour deverbal adjectives suffixed with able (and its allomorphs ible and uble) (Gaatone 1971; Tranel 1976; Dal et al. 2007). Interestingly, Schwarze (2004: 487) notes that in cannot be used with relative adjectives such as grand 'big' and long 'long' or adjectives denoting shapes and colours (e.g. rond 'round', plat 'flat', bleu 'blue'). This semantic constraint is found in other languages, such as English and Italian. Anscombre (1994) also examines the impossibility of using in with some adjectives. He suggests that this phenomenon is semantically grounded and is closely related to the property denoted by the adjective. According to Anscombre, when the adjective denotes a permanent state (e.g. potable 'drinkable'), the prefixation process is impossible (e.g. l'eau *impotable 'undrinkable water'), while for adjectives conveying processes or non-permanent, temporary states, inprefixation is possible. For example, he mentions that résolu 'resolved' (paraphrased as 'who has taken a decision') can be prefixed with in (irrésolu 'unresolved') because it denotes a process (or, at least, a non-permanent, temporary state) while decidé 'decided' (paraphrased as 'who can take decisions') cannot be prefixed (*indécidé 'undecided') because it denotes a permanent state (see Anscombre 1994 for more detail). Mal and mé(s) are also found with the contrary meaning in lexicalised words (e.g. maladroit 'clumsy', malhonnête 'dishonest', malpoli 'impolite', mécontent 'discontented', méconnaissable 'unrecognisable'; see Gaatone 1971).

Dis and $\boldsymbol{d e}$ (and its allomorph dés) are prefixed to nominal bases and express the absence of the entity denoted by the base in nouns (discrédit 'discredit') or the action of 'removing the entity denoted by the noun' in verbs (dératiser 'rid a place of rats') (Amiot 2008). Dé is probably the most productive prefix to convey this meaning, but $e$ is also possible, though much less frequent (écrémer 'remove the cream') (Namer et al. 2003). In view of the fact that $e$, $m a l$ and $m e ́(s)$ are not productive in present-day French (see e.g. Gaatone 1971), they will not be investigated in this paper. In other words, we will only focus on $a, d e ́(s), d i s$, in and non.

\footnotetext{
${ }^{4}$ The reader is referred to Gary-Prieur (1974), Boons (1984), Muller (1990) and Gerhard (1998) for (mainly) generative descriptions of the semantics of $d e ́(s)$. Gerhard (1998), for example, distinguishes between privation (dératiser) and reversal (déboutonner).
} 


\subsubsection{Italian}

Like French, Italian only uses prefixes to coin negative meanings ( $a$, de, dis, in, non and $s) .{ }^{5}$ Iacobini (2004) provides an in-depth meaning-based classification of negative prefixes which is briefly summarised below.

Contradiction is expressed by the prefix non in Italian. According to Iacobini (2004), non is exclusively prefixed to nominal bases, mainly to action and quality nouns (e.g. non-belligerenza 'non-belligerence', non-conformismo 'nonconformity'). When used with abstract nouns, it denotes something that is characterised by the absence of the prototypical characteristics of the base (e.g. nonstoria 'non-story' is a story that does not have the characteristic features of a story). The status of non is rather unclear in Italian grammars, probably because the same form (non) is also used to express syntactic negation. Non is sometimes considered as a prefix in front of both adjectives and nouns, even if it is not graphically related to the base (e.g. i non credenti 'the non-believers', la non disseminazione 'the non-dissemination', il personale non docente 'the nonteaching staff'). Some dictionaries (such as DISC 2003) distinguish between non as an adjectival modifier ('opposite concept in a very attenuative way', as in non facile 'not easy') and non as a nominal modifier ('exact opposite meaning', as in non fumatori 'non-smoker'). When non is used in front of adjectives, it is very close to the grammatical negation non and this questions the very definition of the prefix, as it apparently does not need to be graphically related to the base.

Contrary negation is expressed in Italian by means of $\boldsymbol{i n}, \boldsymbol{a}, \boldsymbol{d i s}$ and sometimes $\boldsymbol{s}$, and is mostly found in adjectives (e.g. indegno 'unworthy', indeciso 'undecided', apartitico 'without any political party', acattolico 'non-catholic', disabitato 'uninhabited', scomodo 'uncomfortable, inconvenient') and, less frequently, in nouns (e.g. incompetenza 'incompetence'). It is important to note here that the prefixed noun may also be analysed as a suffixation of the adjective (e.g. incompetente), an issue that we do not wish to tackle within the scope of this paper. In other words, no claim is made as to the derivational history of the derivatives examined in our study. In terms of productivity, Iacobini (2004) underlines that in and $a$ are the most productive contrary prefixes, while dis and $s$ are less productive.

\footnotetext{
${ }^{5}$ Scalise and Bisetto (2008: 111) include the same prefixes in their inventory of negative prefixes in Italian, adding contro but surprisingly not anti (these two opposition prefixes are not discussed here).
} 
Privation is expressed in Italian by $\boldsymbol{d e}$, dis and $\boldsymbol{s}$. These prefixes mainly attach to nouns to express the lack of the entity denoted by the base (disamore 'lack of love', sfortuna 'lack of luck').

The removal/reversal meaning is expressed in Italian by $\boldsymbol{s}$, dis and $\boldsymbol{d e}$, mainly from verbal and nominal bases (disossare 'remove the bones'). Heuzinger and Schwarze (2002) have underlined that there are two subtypes of $s$ prefixation in Italian, namely Figure and Ground verbs: the first type of $s$ prefixation includes derived verbs that express the removal of the noun base from something (scremare 'remove the cream from something'), while the second one conveys the removal of something from the noun base (scassare 'remove something from a box').

\subsection{Preliminary observations}

As appears from Section 3.2, the classifications and descriptions of negative affixes greatly differ cross-linguistically, as they understandably follow diverging theoretical traditions. Comprehensive descriptions of the entire negative morphological systems of the languages investigated have not been carried out to date. However, a tentative generalisation can be formulated. Among the Latinate negative affixes in English, French and Italian, three major groups seem to emerge: (1) contradictory negation, which is typically conveyed by the prefix non, (2) contrary negation (and privation), conveyed by the prefix in and (3) reversal and removal, conveyed by the prefix $d e$ (En. $d e$, Fr. dé, It. $d i)$. The perimeters of these three groups, however, remain rather unclear. A summary of (Germanic and) Latinate negative affixes is presented in Table 1.

Table 1. Negative affixes in English, French and Italian: a summary.

\begin{tabular}{llll}
\hline & English & French & Italian \\
\hline Contradictory negation & non & non & non \\
Contrary negation, privation & $d e, d i s$, in, un, less & $a, d e ́(s), d i s$, in & $a, d i$, in, $s$ \\
Reversal/Removal & $d e, d i s$, un & $d e ́(s), d i s$ & $d e, d i s, s$ \\
\hline
\end{tabular}




\section{Data and methodology}

\subsection{Corpus description and extraction method}

The present study relies on the Europarl translation corpus (Koehn 2005), which is freely available. ${ }^{6}$ Europarl is made up of the minutes of the European parliament debates, where parliament members can speak in the language of their choice (in many cases, their mother tongue). All speeches and statements are translated into the $25 \mathrm{EU}$ languages. The Europarl corpus itself contains 10 language pairs (English and other European languages). Europarl files are annotated in XML and provide information about the speaker's name and the language used. The major advantage of Europarl is that it is sentence-aligned (which greatly facilitates multilingual data extraction) ${ }^{7}$ and offers large amounts of translated data in a rather wide range of European languages. It is wellknown that compared to monolingual corpora, multilingual corpora tend to be scarce, limited in size and genres (see e.g. Johansson 2007), which makes Euro$\mathrm{parl}$ an invaluable resource for corpus-based contrastive linguistics and translation studies alike.

Table 2 presents the total number of sentences and running words in the English-French and English-Italian Europarl components.

Table 2. The English-French and English-Italian Europarl components.

\begin{tabular}{lcccc}
\hline & $\begin{array}{c}\text { Number } \\
\text { of sentences }\end{array}$ & English tokens & French tokens & Italian tokens \\
\hline English-French & $1,723,705$ & $47,915,991$ & $51,708,806$ & \\
English-Italian & $1,635,140$ & $47,236,441$ & & $46,380,851$ \\
\hline
\end{tabular}

As mentioned above, this paper specifically focuses on the French and Italian translation equivalents of English negative affixes. In other words, only one translation direction is investigated (namely English to French and English to

\footnotetext{
${ }^{6}$ See $<$ http://www.statmt.org/europarl/> (last accessed 17 May 2011).

${ }^{7}$ We could not possibly have relied on word-aligned data, as we were interested in translation patterns where a derivative in the source language corresponds to a multi-word unit or a paraphrase in the target language.
} 
Italian). The other translation directions (French to English and Italian to English, as well as French to Italian and Italian to French), which are of equal interest, will be examined in further studies. In this respect, the major drawback of Europarl is that the information about the source (original) or target (translation) status of the statements is not explicitly available. It is provided for some segments only. In the English file of the English-French subcorpus, 88,577 out of the total 165,009 statements (i.e. 54\%) contain information about the language in which the statement was made. We therefore pre-processed the corpus in order to discard statements that lack this source language information and kept statements where English is clearly identified as the source language and French and Italian as the target languages. After the pre-processing phase, we obtained a trilingual corpus of 10,647 statements (about three million running words per language). As shown in Table 3 , this subcorpus can thus be considered as parallel and directional. ${ }^{8}$

Table 3. Number of running words in the three parts of the Europarl directional corpus used in this study.

\begin{tabular}{ll}
\hline Language & Tokens \\
\hline English & $3,073,076$ \\
French & $3,288,338$ \\
Italian & $3,018,255$ \\
\hline
\end{tabular}

We made use of the ParaConc multilingual concordancer (Barlow 2008) to extract the trilingual concordances, i.e. the English segments (usually sentences) containing the affixed words along with the parallel sentences in French and Italian. Such a tool is of great help to automatically extract the aligned trilingual sentences containing the searched items in the source language. However, in view of the fact that the character strings of the searched affixes (un, in, etc.) can be quite ambiguous (e.g. understand vs. untidy), it was necessary to manual-

\footnotetext{
${ }^{8}$ The term directional corpus refers to a translation corpus where the source and target languages are clearly identified. Even though we cannot confidently assert that the French and Italian texts were not translated on the basis of a pivot language (e.g. Spanish translations of the English original statements), it is highly likely that the English texts were directly translated into French and Italian.
} 
ly weed out the automatically extracted data to get rid of noise. Semantically opaque derivatives were left out and considered as lexicalised. Cross-checking was performed by two analysts. ${ }^{9}$ Some segments ( 37 in total) appeared to be misaligned, both in Italian and French. They were discarded.

\subsection{Data categorisation}

Both source and translated data were categorised following specific criteria. Section 4.2.1 describes the categorisation of the English data while Section 4.2.2 presents the typology used to classify the French and Italian translated data. It should be noted here that translation equivalents have been identified manually. This operation cannot be performed automatically because translation spotting techniques (Huet et al. 2009) are not yet devised to match single words in the source language to their equivalent paraphrases in the target language.

\subsubsection{Categorisation of the English data}

The English data was part-of-speech annotated. Other types of annotation were also added. For instance, when the affixed word was part of a multi-word unit (such as incapacitating gas), it was tagged as such, because it naturally influences its translation. Another annotation was used for prefixes that display both verbal and nominal values (such as $u n$, de and dis). In those cases, we singled out deverbal adjectives (past and present participle bases, bases suffixed in able, etc.), as in disheartened and unmarketable. For the prefix non, we identified the category of the base and the category of the derivative, because non has the potential to form adjectives on the basis of nouns (e.g. a non-priority road).

\subsubsection{Categorisation of the translated data}

A detailed categorisation of the French and Italian translations was also adopted. We first manually part-of-speech tagged the translation equivalents in French and Italian ( $\mathrm{N}$ for noun, $\mathrm{V}$ for verb, $\mathrm{A}$ for adjective, $\mathrm{Adv}$ for adverb). We also relied on two additional tags: $\mathrm{P}$ when the affixed word was translated into a para-

\footnotetext{
${ }^{9}$ This task was performed by the two co-authors.
} 
phrase or a phraseme, i.e. more than one word, and $\mathrm{Z}$ when the meaning conveyed by the affixed word was not translated, viz. zero translation (see Johansson 2007). Within this broad annotation scheme, we classified the translated data according to two major criteria: (1) morphological translations, i.e. the affixed word is translated into a morphologically complex word in the target language, and (2) non-morphological translations. The detailed annotation scheme looks as follows:

- Morphological translations:

- Translation into a congruent affix: the translated word contains a negative affix (En. disunion - Fr. désunion).

- Translation into a non-congruent affix: the translated word contains an affix that does not belong to the negative category (En. non-national insurance - It. società assicurative extranazionali).

- Non-morphological translations:

- Translation into a single word: the translated word is not morphologically complex (e.g. En. unceasing - Fr. constant).

- Translation into a paraphrase: the meaning conveyed by the English affixed word is rendered by a paraphrase in the target language. A subtypology of paraphrases was used to tag some recurrent paraphrase patterns (e.g. Fr. manque de $X$, It. privo di $X$ ). This category also includes multi-word uses (e.g. phrasemes).

- Zero translation: the affixed word is not translated (e.g. En. As the crisis in Afghanistan unfolded, ... - Fr. Face à la crise afghane, ...).

For the English prefix non, we further distinguished between hyphenated and non-hyphenated non translations in French and Italian.

\section{Results}

The classification schemes presented in Section 4.2 and used in the data analysis phase are quite complex and provided huge amounts of cross-linguistic data. In view of the exploratory objectives of this study, the results will be presented in this section following three major axes. For each English affix, we will first discuss the main translation trends by distinguishing between morphological translations, single words, paraphrases and zero translations. When relevant, we will 
zoom in on some parts of speech. We will then focus on the different morphological means that are used in Italian and in French to render English negative affixes (see Section 5.2). Section 5.1 presents the overall trends.

\subsection{General overview}

\subsubsection{English negative affixes in Europarl}

This section briefly presents the English source data. Table 4 summarises the total number of derivatives per affix, both in terms of tokens and types. It also shows the number of types that display a relatively low frequency (frequency $=$ 1 or 2$)$.

Table 4. English negative affixes in Europarl.

\begin{tabular}{lccc}
\hline Affixes & Number of tokens & Number of types & $\begin{array}{c}\text { Number of types with } \\
\text { freq. }=1 \text { or 2 }\end{array}$ \\
\hline$a$ & 31 & 4 & 0 \\
de & 521 & 131 & 60 \\
dis & 1733 & 163 & 73 \\
in & 2282 & 193 & 81 \\
less & 423 & 60 & 23 \\
non & 904 & 284 & 162 \\
un & 4488 & 497 & 261 \\
\hline
\end{tabular}

As shown in Table 4, the number of tokens varies considerably for the seven affixes investigated. The prefix $a$ was excluded from our analysis because of its low frequency. Since we wanted to focus on productive affixes, we decided to analyse low-frequency affixed words (frequency of one or two), as it is wellknown that these hapax legomena or dislegomena often accurately reflect morphological productivity (hapaxes are used, for example, in Baayen's productivity measures; see e.g. Baayen 1992). Words that display a higher frequency are 
more likely to be lexicalised and therefore less interesting from a morphological point of view. Consequently, the analyses described below are exclusively devoted to the six affixes $d e$, dis, in, less, non and un, occurring in words with a frequency of 1 or 2 in our Europarl translation corpus.

Apart from less, which is the only suffix in our data set and is only used to coin adjectives in English, the affixes are used in a range of parts of speech, as shown in Figure 1.

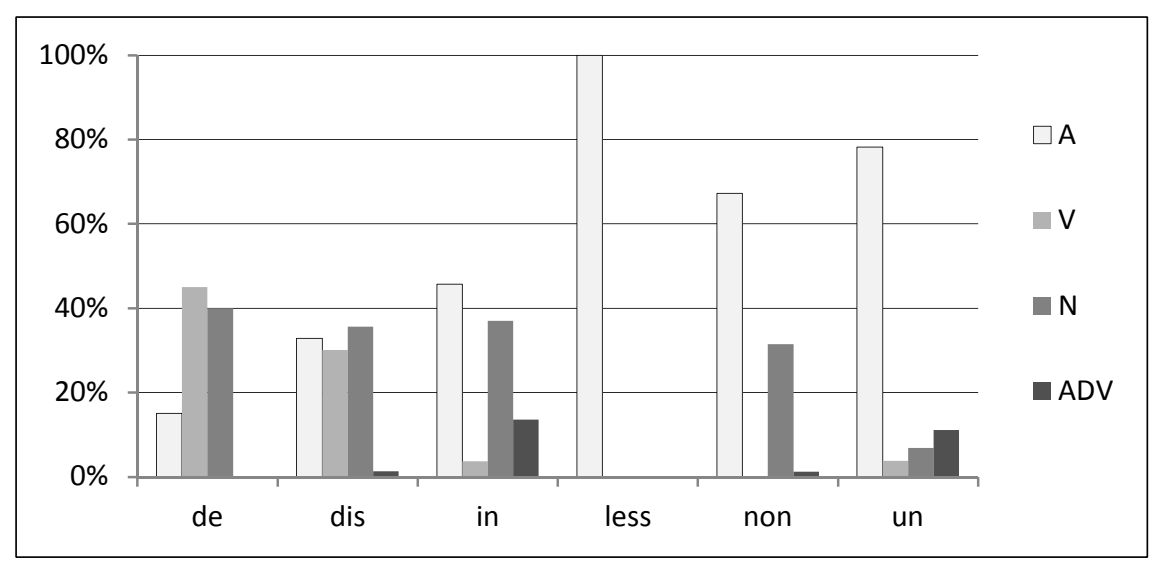

Figure 1. Parts of speech of the derivatives containing English negative affixes.

Two groups of prefixes can be distinguished: first, the prefixes $u n$ and $i n$, which primarily coin adjectives; and second, $d e$ and dis, which mainly coin verbs and deverbal nouns (compared to the other prefixes). The prefix non is mostly used with nouns and adjectives, with a marked preference for adjectives.

The vast majority of adjectives in $u n, d e$ and dis are deverbal (see Table 5). It is noteworthy that these prefixes may consequently convey a reversative meaning in some of the adjectives to which they are prefixed as deverbal adjectives are often ambiguous between the contradictory and reversative interpretations (e.g. an unlocked door: [un[locked]] 'a door that is not locked' or [[unlock]ed] 'a door that has been unlocked').

${ }^{10}$ Their derivational formations differ: $[\text { un }[\text { locked }]]_{\mathrm{A}}<$ locked $_{\mathrm{A}}<$ locked $_{\mathrm{V}}<$ lock $_{\mathrm{V}} \mathrm{vs.}[[\text { unlock }] e d]_{\mathrm{A}}$ $<$ unlocked $_{\mathrm{V}}<$ unlock $_{\mathrm{V}}<$ lock $_{\mathrm{V}}$. 
Table 5. Deverbal adjectives in un, dis and $d e$.

\begin{tabular}{lccc}
\hline & $d e$ & dis & un \\
\hline Deverbal adjectives & 9 & 20 & 173 \\
Not deverbal & 0 & 4 & 31 \\
\hline Total & 9 & 24 & 204 \\
\hline
\end{tabular}

The most frequent deverbal adjectives are past participles (e.g. unaccustomed), followed by the suffixed formations in able (e.g. unassailable) and present participles in ing (e.g. unconvincing) (see Table 6).

Table 6. Types of deverbal adjectives in $u n$, dis and de.

\begin{tabular}{lccc}
\hline Deverbal forms ${ }^{11}$ & de & dis & un \\
\hline Ved & 7 & 13 & 117 \\
Vable & 0 & 4 & 27 \\
Ving & 2 & 3 & 23 \\
Vive & 0 & 0 & 5 \\
Vant & 0 & 0 & 1 \\
Total & 9 & 20 & 173 \\
\hline
\end{tabular}

5.1.2. The French and Italian translations of English negative affixes: General trends

The French and Italian translations of English negative affixes were first classified into four groups to sketch the major translation trends: (1) morphological translations, when the affixed word is translated into an affixed word in the target language; (2) translations into a single (non-morphologically complex) word; (3) paraphrases or phrasemes and (4) zero translation (see Table 7).

\footnotetext{
${ }^{11}$ Deverbal adjectives are abbreviated as follows: $\mathrm{Ved}=$ past participle, $\mathrm{Ving}=$ present participle, Vable $=$ verb suffixed in able or ible, Vive $=$ verb suffixed in ive, Vant $=$ verb suffixed in ant.
} 
Table 7. Morphological translations, single words, paraphrases and zero translations in French and Italian: An overview.

\begin{tabular}{|c|c|c|c|c|c|c|c|c|}
\hline & \multicolumn{4}{|c|}{ French } & \multicolumn{4}{|c|}{ Italian } \\
\hline & $\begin{array}{l}\text { morph. } \\
\text { transl. }\end{array}$ & $\begin{array}{l}\text { single } \\
\text { word }\end{array}$ & $\begin{array}{c}\text { paraphrase } \\
\text { or phraseme }\end{array}$ & $\begin{array}{l}\text { zero } \\
\text { transl. }\end{array}$ & $\begin{array}{l}\text { morph. } \\
\text { transl. }\end{array}$ & $\begin{array}{l}\text { single } \\
\text { word }\end{array}$ & $\begin{array}{c}\text { paraphrase } \\
\text { or phraseme }\end{array}$ & $\begin{array}{c}\text { zero } \\
\text { transl. }\end{array}$ \\
\hline$d e$ & 48 & 8 & 4 & 0 & 44 & 6 & 10 & 0 \\
\hline dis & 44 & 16 & 11 & 2 & 41 & 15 & 15 & 2 \\
\hline in & 48 & 13 & 20 & 0 & 47 & 8 & 24 & 2 \\
\hline less & 5 & 5 & 13 & 0 & 5 & 5 & 13 & 0 \\
\hline non & 111 & 11 & 37 & 3 & 97 & 5 & 59 & 1 \\
\hline un & 87 & 41 & 128 & 5 & 91 & 39 & 123 & 8 \\
\hline
\end{tabular}

The data reveal a clear demarcation between Germanic and Romance affixes. The two Germanic affixes less and un lead to a higher proportion of nonmorphological translations than morphological translations in both French and Italian. The Romance prefixes, by contrast, are more often directly translated into French and Italian negative prefixes (it should be borne in mind that there are no negative suffixes in French and Italian). This ties in with the general claim made in the contrastive literature that Germanic affixes pose more translation problems than Romance affixes, which have direct morphological counterparts in Romance languages (e.g. Chuquet and Paillard 1987). The trends are strikingly similar in the two target languages investigated in this paper (see Figure 2). The similarity in the distribution of the different translation strategies in the two target languages ( $>$ Fr and $>$ It) suggests that translators' choices probably mirror some of the specific features of English negative morphology that can or cannot be easily rendered into French and Italian.

Despite the striking similarities between the French and Italian translation patterns, a notable difference emerges from Figure 2: there seem to be more morphological translations in French than in Italian for the prefix non. This will be examined in Section 5.2.3.

\subsection{Zooming in on individual English affixes and their French and Italian} translations

This section presents an in-depth analysis of the translation strategies adopted for each English affix in French and Italian, focusing more specifically on the 


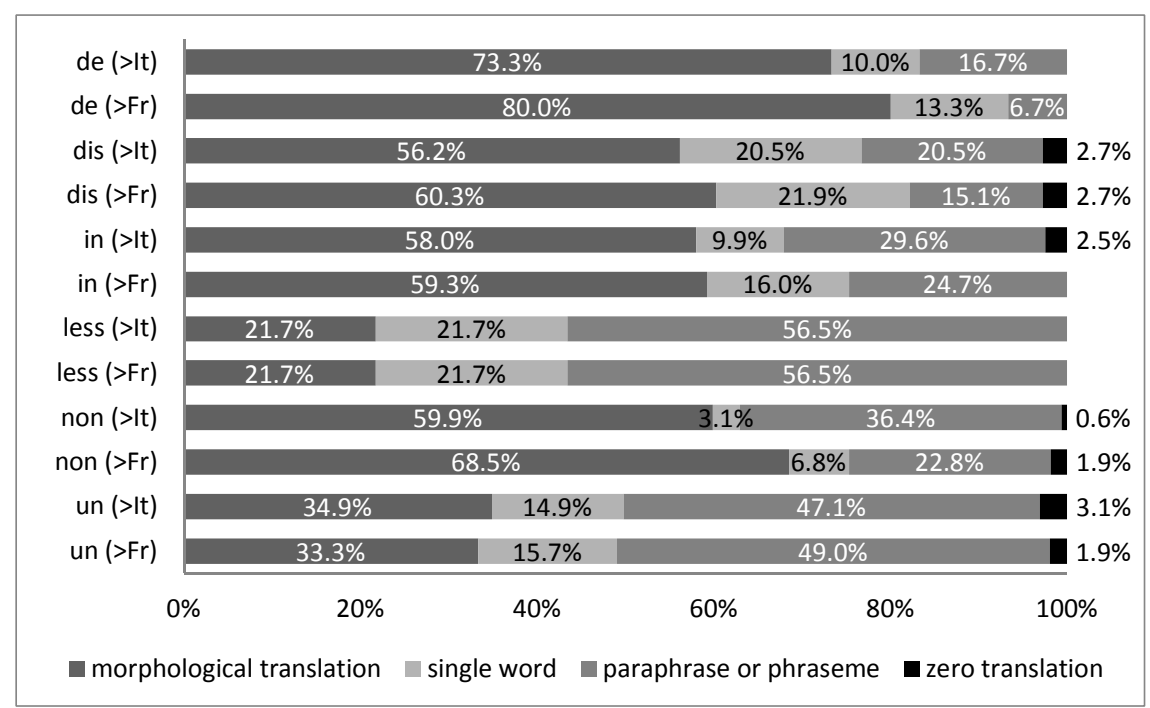

Figure 2. Morphological translations, single words, paraphrases and zero translations in French and Italian: An overview.

morphological translations in each target language and with the aim of sketching some possible contrasts between English negative morphology and its counterparts in French and Italian.

\subsubsection{The prefix $u n$}

\subsubsection{Overview}

This section first describes the broad trends observed in the French and Italian translation data before focusing on the morphological translations. Figure 3 presents the translation patterns in the two target languages.

As already mentioned above, the picture is very similar in Italian and French. The large number of paraphrases (almost $50 \%$ in both languages) points to the possible difficulties encountered by translators to render this Germanic prefix into the two Romance languages. This is illustrated in (3) and (4). 


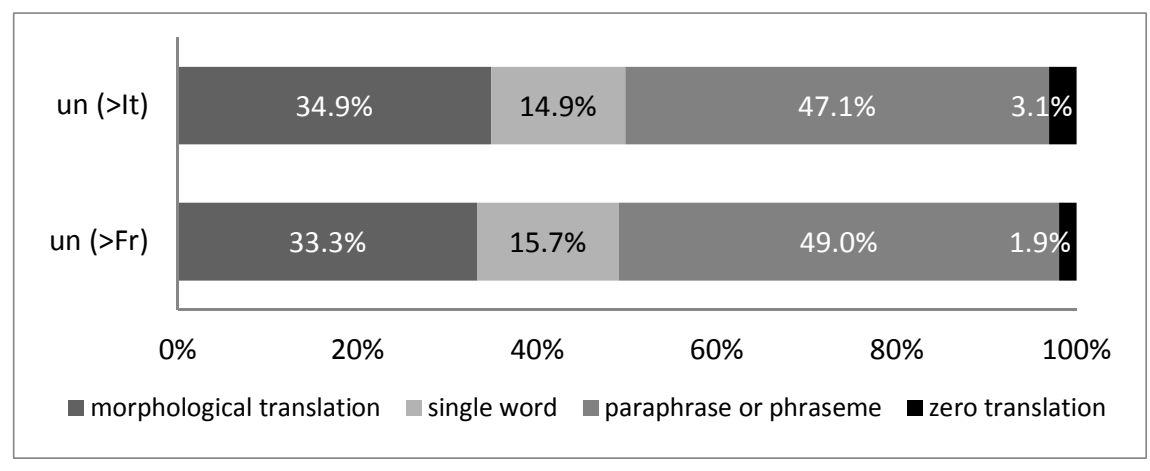

Figure 3. Italian and French translations of the English $u n$.

(3) En. (...) and the faraway places would then be uninteresting deserts for the tourists.

Fr. (...) des régions qui se mueraient par la même occasion en de véritables déserts dépourvus d'intérêt pour les touristes.

It. (...) i luoghi remoti si ridurrebbero a deserti senza alcun interesse per i turisti.

(4) En. The principle of unripe time is always there to slow things down. Fr. Le principe selon lequel le temps n'est pas encore mûr est toujours utilisé pour freiner les choses.

It. Quando si vogliono rallentare le cose, si dice sempre che i tempi non sono maturi (...).

$U n$ is found in adjectives, nouns, verbs and adverbs. It is therefore interesting to have a look at the strategies adopted to translate these four grammatical categories. They are represented in Figure 4.

In both languages, ca. $70 \%$ of the English adjectives prefixed with $u n$ are not translated into French or Italian adjectives containing a negative prefix. This phenomenon is looked into more closely in Section 5.2.1.2. The discrepancy between the translation of $u n$-verbs in Italian and French is also striking at first sight, but since only ten $u n$-verbs were found in the corpus, conclusions cannot be drawn at this stage. 


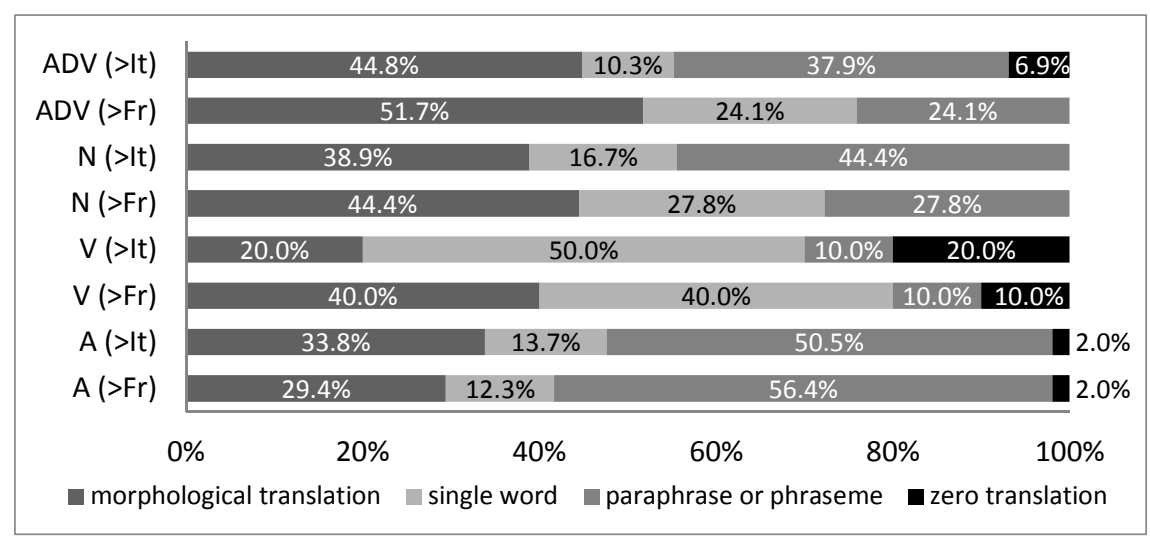

Figure 4. Un translations according to part of speech.

\subsubsection{The translation of $u n$-adjectives}

Un can prefix both deverbal and simplex adjectives. Out of the 204 unadjectives, only 31 are not deverbal (see the category "other" in Figure 5). A large proportion of deverbal adjectives are past participle adjectives (117 tokens), followed by adjectives suffixed in able (27 tokens) and present participles (23 tokens). A few other cases of deverbal adjectives are also observed (one adjective in ant and five adjectives in ive), but they will be excluded from the following discussion.

As appears from Figure 5, the $u n$-adjectives in able are very often translated into a morphologically complex word, which mainly follows the pattern inXble ${ }^{12}$ in French and inXbile in Italian (see (5)). These patterns are very productive in French and Italian (see e.g. Dal et al. 2007).

(5) En. There is a yawning gap, an unbridgeable gap.

Fr. Il y a un gouffre béant, un gouffre infranchissable.

It. Il divario è enorme, incolmabile.

Furthermore, it should be noted that the Italian inXbile is more frequently used than its French counterpart to render the English unXable, as illustrated in (6).

${ }^{12}$ Xble stands for able and its allomorphs ible and uble. 


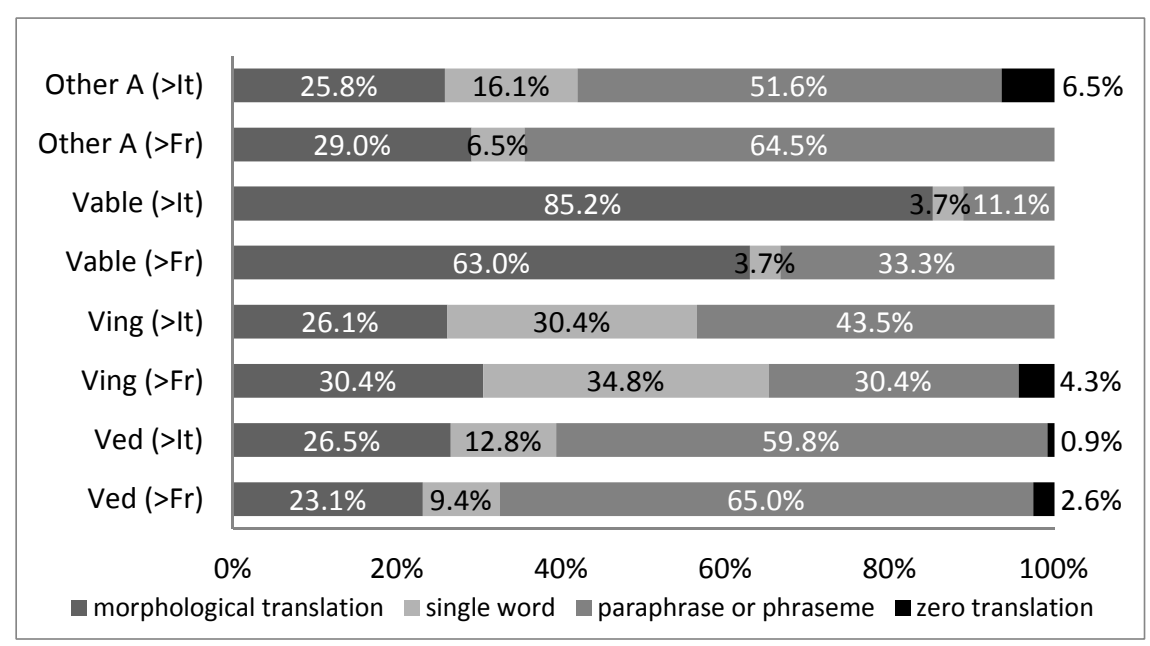

Figure 5. Translations of English un deverbal adjectives.

(6) En. The Labour Party heartlands of Scotland have sent an unmistakable message.

Fr. Le cœur de l'électorat travailliste écossais leur a envoyé un message sans équivoque.

It. Le aree più fedeli della Scozia hanno mandato loro un messaggio inequivocabile.

The patterns inXble in French and inXbile in Italian are also observed in the translations of $u n$-adverbs, as shown in (7). Importantly, French and Italian resort to adjectives and not to adverbs, probably because of the higher productivity of the adverbialiser $l y$ compared to its French and Italian equivalents ment and mente (see Bertrand 1986).
En. unspeakably
Fr. indicible
It. indicibile
En. unarguably
Fr. indubitable
It. indiscutibile
En. undeniably
Fr. indéniable
It. innegabile

The $u n$-adjectives in $e d$ (i.e. formed on the basis of a past participle) are not often translated morphologically. In French, 78 out of 117 unVed adjectives are translated into a paraphrase or a single word devoid of negative affixation and 
this is also the case in Italian, where 69 adjectives are translated into a paraphrase or a single word. We will come back to these translation patterns in Section 5.2.1.4.

\subsubsection{Negative prefixation in Italian and French to render the English $u n$}

The English $u n$ is translated into a negative prefix in ca. one third of the cases in both languages. As shown in Table 8, the French negative in is by far the most frequently used equivalent of un (80\%), followed by dé (about 13\%) (see (8) and (9)). The French dé conveys the idea of reversal and removal, hence its use to render $u n$ in reversative verbs and deverbal adjectives.

Table 8. French prefixes used to render the English un.

\begin{tabular}{lccc}
\hline & dé & in & other \\
\hline $\mathrm{A}$ & 6 & 49 & 3 \\
$\mathrm{~V}$ & 4 & 0 & 0 \\
$\mathrm{~N}$ & 0 & 6 & 2 \\
$\mathrm{ADV}$ & 1 & 13 & 1 \\
\hline Total & 11 & 68 & 6 \\
\hline Percentage & $12.94 \%$ & $80 \%$ & $7.06 \%$ \\
\hline
\end{tabular}

(8) En. unforeseeable

Fr. imprévisible

En. undisputable

Fr. incontestable

En. unanticipated

Fr. imprévu

En. unwary

Fr. imprudent

En. unbelievably

Fr. incroyablement

En. unwillingly

Fr. involontairement

En. unpopularity

Fr. impopularité 
(9) En. Preceding the downfall of the Roman Empire it was customary to take out the imperial decree, unroll the great scroll of purple and gold (...).

Fr. Avant la chute de l'Empire romain, il était habituel de présenter le décret impérial, de dérouler le grand rouleau pourpre et or (...).

In Italian, the negative in is also the most frequently used equivalent of un $(86.52 \%)$ (see Table 9 and the examples listed in (10)). The other negative prefixes are marginal in translated Italian.

Table 9. Italian prefixes used to render the English un.

\begin{tabular}{lccc}
\hline & in & $s$ & other \\
\hline $\mathrm{A}$ & 60 & 2 & 5 \\
$\mathrm{~V}$ & 0 & 1 & 1 \\
$\mathrm{~N}$ & 6 & 1 & 0 \\
$\mathrm{ADV}$ & 11 & 1 & 1 \\
\hline Total & 77 & 5 & 7 \\
\hline Percentage & $86.52 \%$ & $5.62 \%$ & $7.87 \%$ \\
\hline
\end{tabular}

(10)
En. undefinable
It. indefinibile
En. unadapted
It. inadatto
En. unbroken
It. inviolato
En. uninhabitable
It. inabitabile
En. unwarrantedly
It. indebitamente
En. unwillingly
It. involontariamente
En. unsuitability
It. inadeguatezza

\subsubsection{Translations into a paraphrase with non}

Interestingly, non is used to translate $u n$-adjectives in around one third of the cases where a paraphrase is used in French and Italian. 
Table 10 summarises the importance of the non paraphrases in French and Italian. Most of the $u n$-words that are translated into a paraphrase with non are un $\mathrm{Ved}$ adjectives.

Table 10. Non paraphrases to translate English un-adjectives.

\begin{tabular}{lccc}
\hline & $\begin{array}{c}\text { Morphological } \\
\text { translations }\end{array}$ & $\begin{array}{c}\text { Translations } \\
\text { into a paraphrase }\end{array}$ & Paraphrases with non \\
\hline French & 60 & 91 & 30 \\
Italian & 69 & 100 & 26 \\
\hline
\end{tabular}

UnVed adjectives can be divided into two groups on the basis of the translation patterns uncovered in Europarl. On the one hand, we find unVed adjectives such as unadapted, uncompleted, unexplained, etc., which have a direct morphological translation in French and Italian, namely a complex word with the prefix in (see (11)); on the other hand, we find unVed adjectives such as $u n$ armed, unstated, unfiltered, unnamed, unplanned, unpublished, unregistered, etc., which were all translated into a paraphrase with non in French and Italian (see (12)).
En. unadapted
Fr. inadapté
It. inadatto
En. uncompleted
Fr. inachevé
It. incompleto
En. unexplained
Fr. inexpliqué
It. inspiegato
En. unarmed
Fr. non armé
It. non armato
En. unstated
Fr. non déclaré
It. non dichiarato
En. unfiltered
Fr. non filtré
It. non filtrato
En. unnamed
Fr. non cité
It. non meglio identificato
En. unplanned
Fr. non planifié
It. non programmato
En. unpublished
Fr. non publié
It. non pubblicato
En. unregistered
Fr. non enregistré
It. non registrato

A similar - yet not corpus-informed - observation was made in Schwarze (2005), which presents a number of English un-adjectives (such as unclear, un- 
safe, untrue, unkind, unnecessary) that have a similar morphological equivalent in German, but no possible morphological equivalent in Italian or French. In Schwarze's study, those examples are provided to exemplify the limited productivity of the French prefix in. According to Schwarze, the impossibility of using in with some French adjectives is etymologically grounded. Inprefixed words appeared in French only from the 14th century onwards and were borrowed from Latin. Before that, in the early classical Old French, "there were virtually no in-prefixed adjectives [...], and most of the French adjectives that do not have an in-prefixed form are adjectives from the GalloRomance heritage (clair, sûr, vrai). Before the 14th century, to fill the gap, [...] new, native lexical negation emerged and left traces in today's lexicon" (as in maladroit 'clumsy', mécontent 'discontent', malheureux 'unhappy' (Schwarze 2005: 155)).

In our view, several hypotheses can be put forward to account for this apparent discrepancy between English on the one hand and French and Italian on the other. First, the data in (12) are made up of $u n V e d$ adjectives that are clearly contradictory and, as previously mentioned, the typical item that conveys contradictory negation in French and Italian is non. Second, in the data presented in (12), the prefixation in in seems to be impossible in French and Italian (e.g. Fr. *indéclaré, *impublié, *inenregistré; It. *inregistrato, *inarmato) and consequently leads to the use of non. In this respect, Gaatone (1971: 17-18, 22-23) has underlined that the French prefix in is not compatible with verbs or with the verbal features of some adjectives (such as past participles). Gaatone mentions the noun phrases une maison habitée / inhabitée ('an inhabited house / an uninhabited house') and une maison habitée / *inhabitée par des ouvriers ('a house inhabited by workers / a house uninhabited by workers') and argues that French has to resort to non in cases where adjectives display a strong verbal force (as is the case in the noun phrases complemented by the par 'by' phrase) (note that non is compatible with the verbal features of some adjectives, e.g. un sentiment non explicable en mots humains 'a feeling non explainable in human words'). This possibly ties in with Anscombre's (1994) claim that in-prefixation is only possible in front of adjectives denoting processes and not in front of adjectives denoting permanent states. An alternative explanation, found in Schwarze (2004, 2005), would be that only some in-prefixation patterns are still productive in present-day French and Italian (e.g. Fr. inVble, It. in Vbile). These competing - but complementary - hypotheses would need to be checked against corpus data in follow-up studies. 


\subsubsection{The prefix in}

\subsubsection{Overview}

As shown in Figure 6, the translation strategies used to render the English in are very similar in the two target languages.

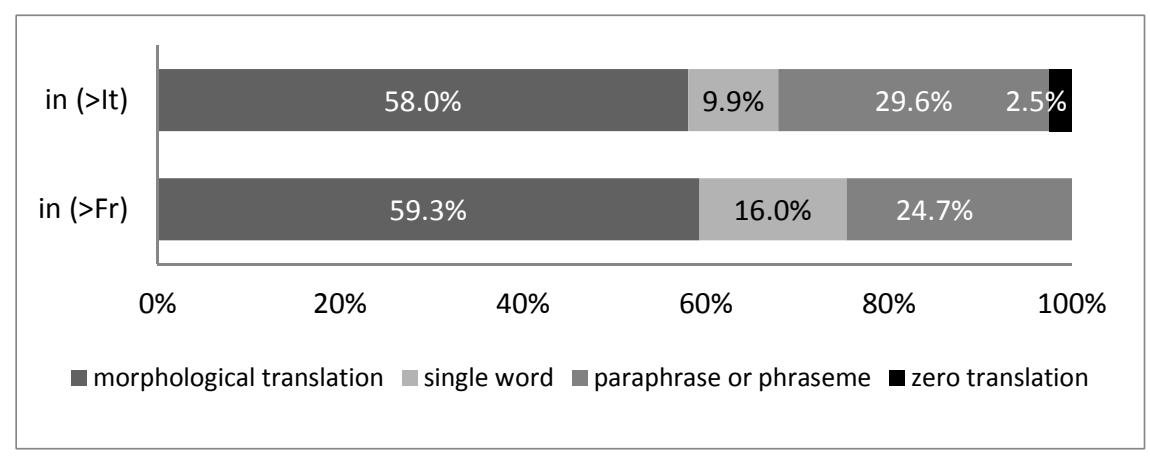

Figure 6: Italian and French translations of the English in.

Compared to $u n$, the translation data in Figure 6 display fewer paraphrases and phrasemes and many more morphological translations. In other words, in is often translated into a negative prefix in French and Italian.

Paraphrases and single words devoid of prefixation account for $24.69 \%$ and $16.05 \%$ of the French data, respectively. Paraphrases mainly include the noun manque 'lack of' and the verb manquer 'to lack' or a grammatical negation (see (13) to (15)). The use of manque and manquer to render the English in shows the close link between contrary and privative negation (often paraphrased as 'lack of').

(13) En. The live export incident involving Germany and the Lebanon this summer resulted from the inexperience of the German authorities (...). Fr. L'incident de transport de bétail vivant impliquant l'Allemagne et le Liban qui s'est produit cet été était dû au manque d'expérience des autorités allemandes (...). 
(14) En. It is after all an inelastic supply in certain circumstances, just as it is with doctors in training.

Fr. Après tout, nous nous retrouvons, somme toute, face à un manque d'élasticité de l'offre dans certaines circonstances, comme c'est le cas pour les médecins en formation.

(15) En. Future generations will pay a price for our inactivity in this very important subject.

Fr. Les générations futures paieront un lourd tribut si nous n'agissons dans ce très important domaine.

Single words are all cases of modulation, i.e. a change in viewpoint (e.g. En. indignity vs. Fr. honte 'shame'; En. insufficiency vs. Fr. lacune 'lacuna'). Paraphrases are somewhat more frequent in Italian than French and include, among others, grammatical negations, the noun mancanza 'lack of' and the adjective privo 'without', which again points to the closeness of contrary negation and privation. Examples are provided in (16) and (17).

(16) En. I have also tabled an amendment expressing great concern about this idea of inexperienced European volunteers going into what are often very complex humanitarian situations (...).

It. Ho anche presentato un emendamento per esprimere forti preoccupazioni sull'ipotesi di mandare volontari europei privi di esperienza ad affrontare situazioni umanitarie che sono spesso molto complesse (...).

(17) En. (...) it is too difficult in many cases to employ people because of the red tape and the regulation and the inflexibility of the labour markets. It. (...) in molti casi è difficile assumere personale a causa delle lungaggini burocratiche, della normativa e della mancanza di flessibilità del mercato del lavoro.

\subsubsection{Negative prefixation in Italian and French to render the English in}

As can be seen from Table 11, English in-derivatives are translated into French in-derivatives in ca. $98 \%$ of the cases (there is only one case where in is translated into non). Illustrations are listed in (18). 
Table 11. The French translation of the English in.

\begin{tabular}{lcc}
\hline & in & other \\
\hline $\mathrm{A}$ & 26 & 0 \\
$\mathrm{~V}$ & 2 & 0 \\
$\mathrm{~N}$ & 18 & 1 \\
$\mathrm{ADV}$ & 1 & 0 \\
\hline Total & 47 & 1 \\
\hline Percentage & $97.92 \%$ & $2.08 \%$ \\
\hline
\end{tabular}

(18)
En. indeterminate
Fr. indéterminé
En. inescapable
Fr. incontournable
En. insensitivity
Fr. insensibilité

Similar results are observed in Italian, as appears from Table 12 and the examples listed in (19). The other prefix used to translate in is $d i$ (one occurrence only).

Table 12. The Italian translation of the English in.

\begin{tabular}{lcc}
\hline & in & other \\
\hline $\mathrm{A}$ & 22 & 0 \\
$\mathrm{~V}$ & 2 & 1 \\
$\mathrm{~N}$ & 19 & 0 \\
$\mathrm{ADV}$ & 3 & 0 \\
\hline Total & 46 & 1 \\
\hline Percentage & $97.87 \%$ & $2.13 \%$ \\
\hline
\end{tabular}

(19)
En. incalculable
It. incalcolabile
En. inseparable
It. indissociabile
En. inaccessibility
It. inaccessibilità 


\subsubsection{The prefix non}

\subsubsection{Overview}

The English non is found in 109 adjectives and 51 nouns. As mentioned in Section 3, the status of non is rather ambiguous in Italian and French (prefix with nominal bases vs. adverb in front of adjectives). In view of this unclear status in the two target languages, the categorisation of the translation data in terms of grammatical categories is less pertinent. In the present section, we will distinguish between two main patterns: (1) when the target language resorts to the direct counterpart non and (2) when the target language resorts to other translation strategies. Figure 7 presents the distribution of the different translation strategies. The category 'morphological translation' stands for translations containing non, whether hyphenated or not.

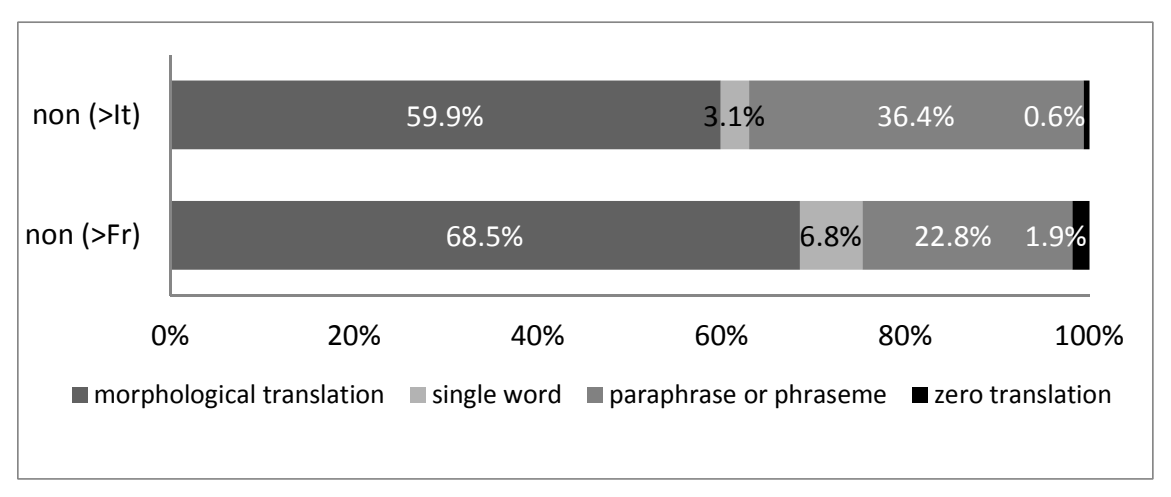

Figure 7. The Italian and French translations of the English non.

Paraphrases are frequent: they account for nearly one fourth of the translations in French and one third in Italian. In French, they include, among others, the grammatical negation ne ... pas, the adverb non used on its own, absence, autre que 'other than' and manque 'lack of'. In Italian, they include patterns containing the grammatical negation non ..., the adverb non used on its own, mancato 'missed, failed' and senza 'without'. 
5.2.3.2. Negative prefixation in Italian and French to render the English non

Negative prefixes other than non are rarely used, as can be seen from

Table 13. These include $a$, dé and in in French and in in Italian (see (20)).
En. non-political
Fr. apolitique
En. non-profitable
Fr. désintéressé
En. non-legal
Fr. illégal
En. non-direct
It. indiretto

Italian also uses two non-congruent prefixes. For example, extra is used to render the English non (as in It. extra-nazionale as a translation of non-national). In this case, the negative meaning of non (denying the quality of being national) is rendered by a construction that denotes something which is 'outside the country'.

Table 13. French and Italian prefixes used to render the English non.

\begin{tabular}{|c|c|c|c|c|c|c|}
\hline & \multicolumn{3}{|c|}{ French } & \multicolumn{3}{|c|}{ Italian } \\
\hline & non & $\begin{array}{c}\text { other } \\
\text { congruent } \\
\text { prefixes }\end{array}$ & $\begin{array}{c}\text { non- } \\
\text { congruent } \\
\text { prefixes }\end{array}$ & non & $\begin{array}{c}\text { other } \\
\text { congruent } \\
\text { prefixes }\end{array}$ & $\begin{array}{c}\text { non- } \\
\text { congruent } \\
\text { prefixes }\end{array}$ \\
\hline $\mathrm{A}$ & 72 & 5 & 0 & 67 & 4 & 2 \\
\hline $\mathrm{V}$ & 0 & 0 & 0 & 0 & 0 & 0 \\
\hline $\mathrm{N}$ & 33 & 0 & 0 & 21 & 2 & 0 \\
\hline $\mathrm{ADV}$ & 1 & 0 & 0 & 1 & 0 & 0 \\
\hline Total & 106 & 5 & 0 & 89 & 6 & 2 \\
\hline Percentage & $95.5 \%$ & $4.5 \%$ & $0 \%$ & $91.75 \%$ & $6.18 \%$ & $2.06 \%$ \\
\hline
\end{tabular}

The use of the hyphen with the French non when it is used to render English non-derivatives is highly inconsistent (see Table 14). The general trend, which is in line with descriptions and recommendations found in French grammars, is that non is hyphenated to nouns (where it acts as a prefix) and written as two words when used in combination with adjectives (where it acts as an adverb). However, we find a number of counter-examples in our data (see (21)), which probably point to the blurred status of non in French, or, at least, to its inconsistent use by the translators represented in our corpus. 
Table 14. The use of the French non to translate English non-derivatives.

\begin{tabular}{lcc}
\hline & Written as two words & Hyphenated \\
\hline $\mathrm{A}$ & 66 & 6 \\
$\mathrm{~N}$ & 7 & 26 \\
$\mathrm{ADV}$ & 1 & 0 \\
\hline Total & 74 & 32 \\
\hline Percentage & $69.81 \%$ & $30.19 \%$ \\
\hline
\end{tabular}
En. non-strategic
Fr. non-stratégique
En. non-inclusion
Fr. non inclusion

The hyphenation of non to adjectives can also be observed in original French, as illustrated in the examples (22) to (26), which were extracted from the French component of the Louvain Multilingual Corpus of Editorials (Mult-Ed) and from the KIAP corpus of research articles (Fløttum et al. 2006).

(22) Rappelons cependant qu'après des décennies d'orthodoxie non-interventionniste, Keynes conteste l'aptitude du capitalisme à assurer par lui-même un équilibre économique de plein emploi et à sortir rapidement des phases de récession. (Mult-Ed)

(23) Nous avons isolé les experts selon leur degré de connaissance selon deux groupes : les experts compétents (qui déclarent une "très grande" et "grande" connaissance) et les experts non-compétents (qui déclarent une connaissance "limitée"). (KIAP)

(24) Sans doute est-ce cette caractéristique qui explique que grand puisse avoir des emplois semi-déterminatifs : grand peut être à même de construire, à l'aide d'un trait qualitatif, ce qui serait une quantité, définie alors comme particulièrement importante puisque non-contiguë à toute évaluation. (KIAP)

(25) Étant donné le caractère aléatoire de la prospection du marché, la distribution des encaisses des individus est non-dégénérée : il en va donc, de même, pour la distribution des prix. (KIAP) 
(26) Les préférences des consommateurs et les prix non-linéaires proposés à l'équilibre par chaque concurrent de telle façon que chacune de ces firmes concurrentes ne soit intéressée que par un agrégat entre les préférences de l'acheteur pour le bien qu'elle propose et les tarifications de ses concurrentes. (KIAP)

The trend is somewhat different in Italian, where [non + adjective/noun] sequences are both frequently written as two words (see Table 15). Examples are listed in (27).

Table 15. The use of the Italian non to translate English non-derivatives.

\begin{tabular}{lcc}
\hline & Written as two words & Hyphenated \\
\hline $\mathrm{A}$ & 64 & 3 \\
$\mathrm{~N}$ & 14 & 7 \\
$\mathrm{ADV}$ & 0 & 1 \\
\hline Total & 78 & 11 \\
\hline Percentage & $87.64 \%$ & $12.36 \%$ \\
\hline
\end{tabular}
En. non-dialogue
It. non dialogo
En. non-membership
It. non adesione
En. non-banking
It. non bancario
En. non-official
It. non ufficiale

5.2.3.3. The bases of non-words in the source and target languages

The English non can apply to nominal bases to coin adjectives and nouns and to adjectival bases to coin adjectives. These three different cases are not as frequent in the data (see Table 16). ${ }^{13}$

\footnotetext{
${ }^{13}$ Two non-words are adverbs and were not included in this table.
} 
Table 16. Adjectival and nominal bases of English non-words.

\begin{tabular}{lc}
\hline POS base $>$ POS derivative & $\#$ \\
\hline A $>$ A & 86 \\
N $>$ A & 23 \\
N $>$ N & 51 \\
\hline
\end{tabular}

Interestingly, this seems to have an impact on the translation patterns in French and Italian, which are markedly different in the two target languages, as shown in Figure 8.

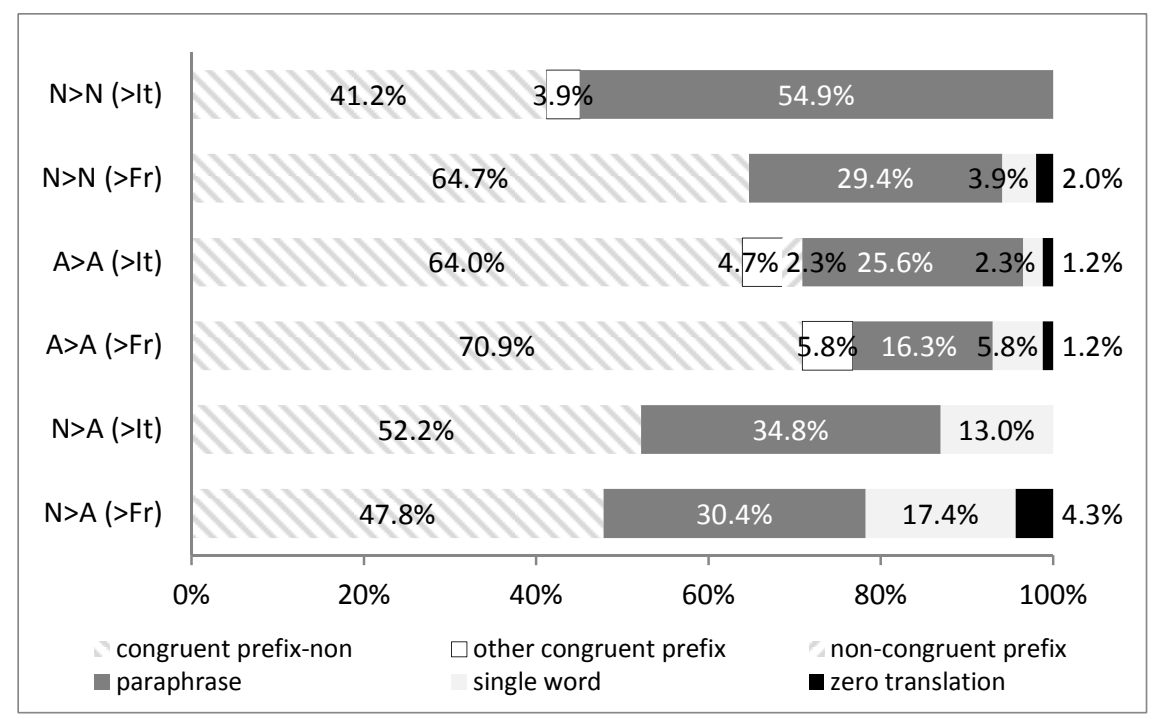

Figure 8. Translation of the English non according to the POS of the base and the POS of the derivative.

The $\mathrm{N}>\mathrm{N}$ non prefixation pattern is more frequently translated into non in French. In the majority of the cases where the English non $(\mathrm{N}>\mathrm{N})$ is translated into the French non $(\mathrm{N}>\mathrm{N})$, it is translated into an Italian paraphrase where the noun is modified by the adjective mancato 'missed', as shown in (28). 

En. non-inclusion
Fr. non inclusion
It. mancata inclusione
En. non-fulfilment
Fr. non réalisation
It. mancata attuazione
En. non-taxation
Fr. non-imposition
It. mancata imposizione
En. non-participation
Fr. non-participation
It. mancata partecipazione
En. non-decision
Fr. non-décision
It. decisione mancata

The translation of the prefix non clearly shows that even if a word-formation element is shared across languages, it can nevertheless display very different behaviours from a language to another.

\subsubsection{The prefix dis}

\subsubsection{Overview}

The prefix dis, like de (see Section 5.2.5), is of Romance origin and is consequently often translated into its Romance counterparts in Italian and French, as shown in Figure 9.

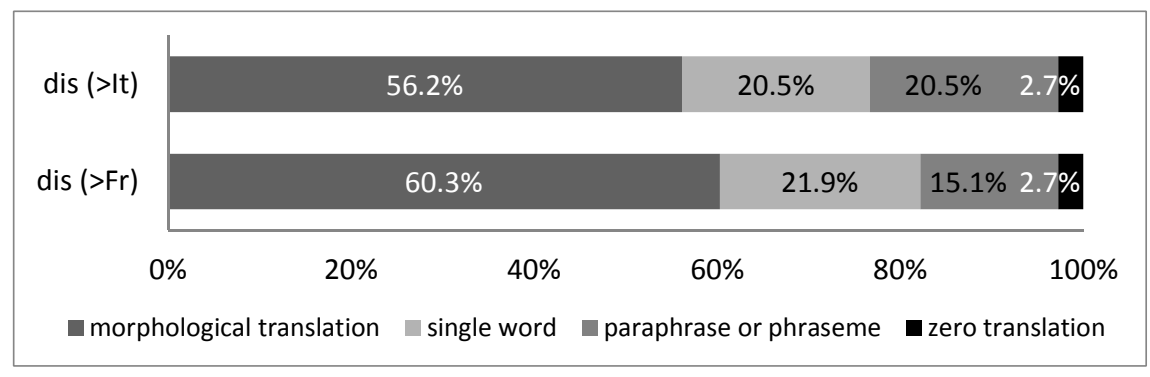

Figure 9. Italian and French translations of the English dis.

In both target languages, translations into a single word devoid of prefixation and paraphrases are also quite common (they account for ca. $40 \%$ of the data), as illustrated in (29) and (30). 

En. distaste
Fr. aversion
It. avversione
En. disapplication
Fr. suppression
It. abolizione

(30) En. (...) many of them are very slow and disinclined to do it in the way that we would like.

Fr. (...) nombre d'entre eux sont très lents et peu enclins à le faire de la façon dont nous le souhaiterions.

It. (...) molti sono piuttosto lenti e ben poco propensi a farlo nel modo in cui auspichiamo.

5.2.4.2. Negative prefixation in Italian and French to render the English dis

The most frequently used prefix to translate dis into French is dé (see Table 17). The other prefixes, namely dis and in, are much less frequent. We also found one occurrence of mal and mé. Examples are provided in (31).

Table 17. French prefixes to render the English dis.

\begin{tabular}{lcccc}
\hline & dé & dis & in & other \\
\hline $\mathrm{A}$ & 10 & 0 & 3 & 1 \\
$\mathrm{~V}$ & 14 & 1 & 0 & 0 \\
$\mathrm{~N}$ & 13 & 1 & 0 & 1 \\
$\mathrm{ADV}$ & 0 & 0 & 0 & 0 \\
\hline Total & 37 & 2 & 3 & 2 \\
\hline Percentage & $84.09 \%$ & $4.55 \%$ & $6.82 \%$ & $4.55 \%$ \\
\hline
\end{tabular}

(31)
En. disintegrate
Fr. se désintégrer
En. disobedience
Fr. désobéissance
En. disconnection
Fr. déconnexion
En. disrespectful
Fr. irrespectueux
En. discontinuity
Fr. discontinuité 
The Italian dis stands out as being the most frequently used equivalent prefix (especially when prefixed to nouns and verbs), but other prefixes, such as $s$, are also quite common, particularly in verbs (see Table 18 and (32)).

Table 18. Italian prefixes to render the English dis.

\begin{tabular}{lcccc}
\hline & dis & de & in & $s$ \\
\hline $\mathrm{A}$ & 4 & 3 & 3 & 3 \\
$\mathrm{~V}$ & 8 & 0 & 0 & 6 \\
$\mathrm{~N}$ & 12 & 0 & 0 & 2 \\
$\mathrm{ADV}$ & 0 & 0 & 0 & 0 \\
\hline Total & 24 & 3 & 3 & 11 \\
\hline Percentage & $58.54 \%$ & $7.32 \%$ & $7.32 \%$ & $26.83 \%$ \\
\hline
\end{tabular}
En. disillusion
It. disillusione
En. disorientation
It. disorientamento
En. disapprove
It. disapprovare
En. discredit
It. screditare
En. discourage
It. scoraggiare

\subsubsection{The prefix $d e$}

\subsubsection{Overview}

The English de attaches to verbs and deverbal nouns, where it mainly conveys the negative sub-meanings of reversal and removal. As for dis, since it is a Romance prefix, we notice that it can very easily be translated into a congruent prefix in Italian and French (see Figure 10).

5.2.5.2. Negative prefixation in Italian and French to render the English de

$D e$ is nearly always translated into French by dé when a morphological translation is used in French (as shown in Table 19). Illustrations are listed in (33). 


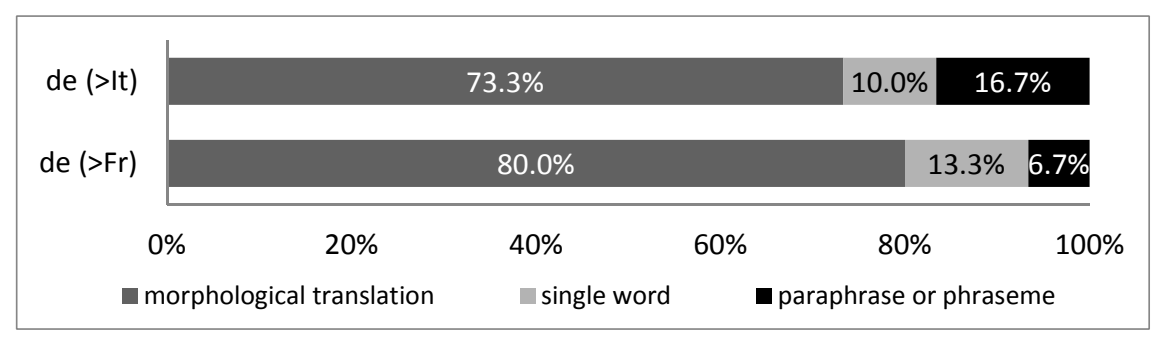

Figure 10. Translations of the English de.

Table 19. French prefixes used to translate the English $d e$.

\begin{tabular}{lcc}
\hline & dé & non \\
\hline $\mathrm{A}$ & 5 & 0 \\
$\mathrm{~V}$ & 22 & 0 \\
$\mathrm{~N}$ & 20 & 1 \\
$\mathrm{ADV}$ & 0 & 0 \\
\hline Total & 47 & 1 \\
\hline Percentage & $97.9 \%$ & $2.1 \%$ \\
\hline
\end{tabular}

(33) En. deinstitutionalisation

Fr. désinstitutionnalisation

En. decentralise

Fr. décentraliser

En. depoliticise

Fr. dépolitiser

En. dehydrated

Fr. déshydraté

However, in Italian, three prefixes are used to render de (see Table 20). Examples are given in (34).

Table 20. Italian prefixes used to translate the English $d e$.

\begin{tabular}{lccc}
\hline & $d e$ & dis & $s$ \\
\hline $\mathrm{A}$ & 1 & 2 & 2 \\
$\mathrm{~V}$ & 15 & 0 & 5 \\
$\mathrm{~N}$ & 12 & 1 & 6 \\
$\mathrm{ADV}$ & 0 & 0 & 0 \\
\hline Total & 28 & 3 & 13 \\
\hline Percentage & $63.64 \%$ & $6.82 \%$ & $29.55 \%$ \\
\hline
\end{tabular}



En. decriminalisation
It. depenalizzazione
En. destabilise
It. destabilizzare
En. demobilise
It. smobilitazione ${ }^{14}$
En. deboned
It. disossato

There is thus a wider variety of equivalents in Italian than in French, which seems to rely exclusively on dé to render the English de morphologically. In Italian, as underlined by Iacobini (2004: 145), de has a similar value and function as $s$ and some parallel formations co-exist (e.g. demagliare/smagliare, defogliare/sfogliare), where the derivative in de belongs to a more formal register or to the scientific-technical domain. In our data, only one parallel formation was found (demilitarizzazione/smilitarizzazione), both used to translate En. demilitarisation.

\subsubsection{The suffix less}

Even though there were only 23 occurrences of less-derivatives (with freq. $=1$ or 2) in our corpus, some interesting remarks can be formulated. First, as can be seen from Figure 11, the results are strikingly similar in the two target languages, where more than half of the less-words are translated into a paraphrase. French paraphrases mainly contain sans 'without' while the majority of Italian paraphrases either contain senza 'without' or privo di 'lacking' or a grammatical negation, which confirms that less mainly conveys privation (see (35) and (36)).

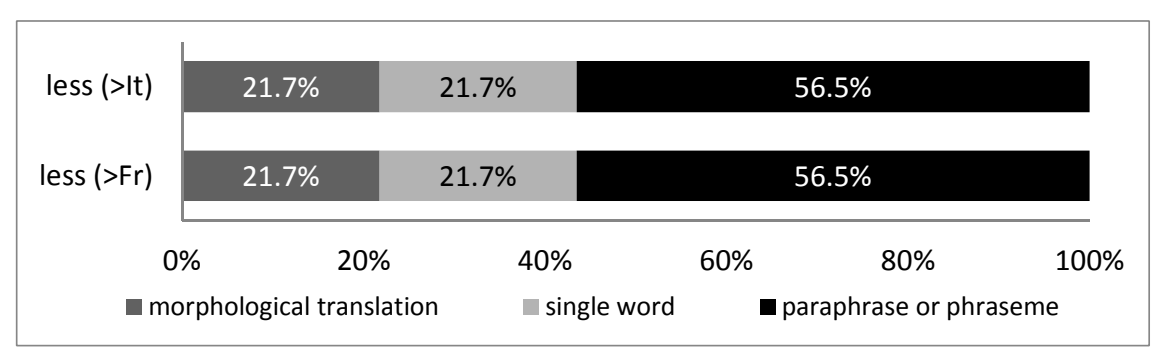

Figure 11. French and Italian translations of the English less.

\footnotetext{
${ }^{14}$ Noteworthy here is that the English verb is translated into a deverbal noun in Italian, which contains a congruent prefix.
} 
(35) En. With a borderless Europe these choices can only be made together, rather than separately.

Fr. Avec une Europe sans frontières, nous pouvons seulement faire ces choix ensemble, plutôt que séparément.

It. In un'Europa senza frontiere, queste scelte possono solo essere fatte insieme, e non separatamente.

(36) En. (...) you end up being trapped for over half a day in an airless room by total strangers (...).

Fr. (...) cette personne se retrouve coincée par de parfaits inconnus pendant une demi-journée dans une pièce sans air (...).

It. (...) di finire entrambi intrappolati da persone totalmente estranee in una stanza priva d'aria per più di mezza giornata (...).

Second, it should be emphasised that the low proportion of morphological translations (less than a fourth; see illustrations in (37)) are due to the fact that less has no direct equivalent in Italian and French. A meaning shift is observed in the translations, where the privative meaning conveyed by less is rendered by the contrary meaning of $i n$.
En. priceless
Fr. inestimable
It. inestimabile
En. valueless
Fr. inutile
It. inutile

\section{Discussion}

The present study has made use of trilingual translation corpus data with a view to sketching the main contrasts between English, Italian and French negative affixation. This section summarises our main findings.

The results seem to confirm the causal link between cross-linguistic morphological differences and non-morphological translations (e.g. single words devoid of negative affixation and paraphrases). The two Germanic affixes investigated in this paper, namely $u n$ and less, were found to display the highest proportions of non-morphological translations in Italian and French. English Romance affixes, by contrast, seem to be relatively easy to translate into Italian and French, as they often correspond to their cognate equivalents in the target languages. However, they also lead to a non-negligible number of nonmorphological translations, which would certainly be worth looking at more closely in a follow-up study. A number of categories of English affixed words 
were found not to have any morphological equivalent in Italian or French. In the case of Ved-adjectives prefixed in $u n$, for example, we have observed that while adjectives such as unadapted and uncompleted can be morphologically translated into French and Italian (with the prefix in), other unVed adjectives such as unpublished, unrecorded, unregistered, etc. have no morphologically constructed counterparts in Italian and French. As mentioned above, this could be explained by semantic and etymological constraints on the prefix in in French and Italian.

The corpus-based study has also revealed striking similarities in the Italian and French translations of English negative affixes. It has shown that the English prefixes non and $i n$ are often translated into their direct counterparts in Italian and French (non and in, respectively). The cognate prefixes are used in ca. $95 \%$ of the morphological translations in both target languages, as illustrated in Figure 12 and Figure 13.

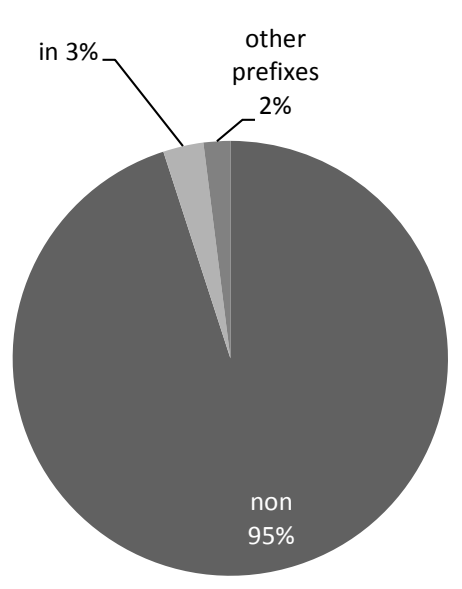

French

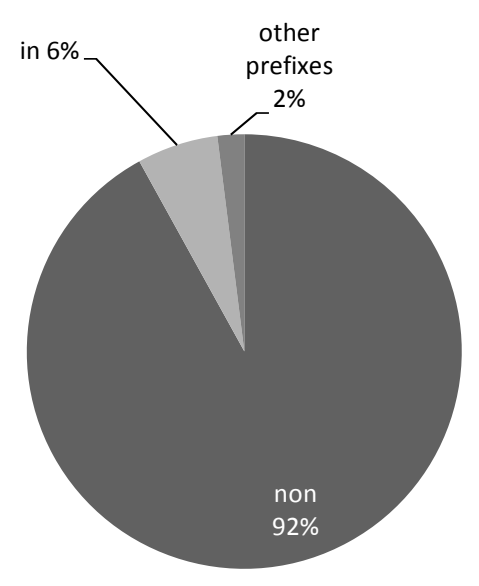

Italian

Figure 12. The English non and its French and Italian equivalents.

The systematic comparison of the translation patterns in the two target languages has also made it possible to further uncover an interesting contrast between Italian and French negative morphology. While dé accounts for $98 \%$ of the morphological translations of the English de in French, three different rever- 


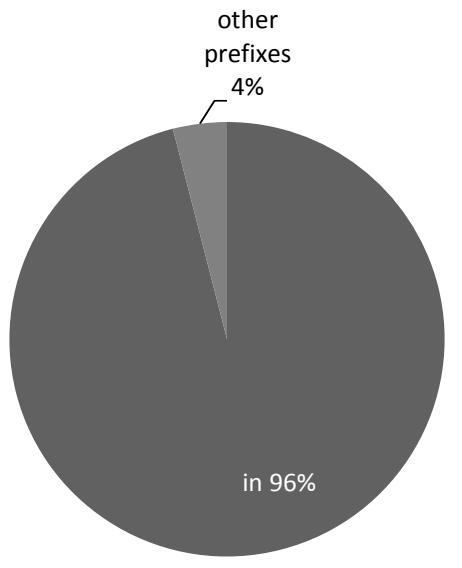

French

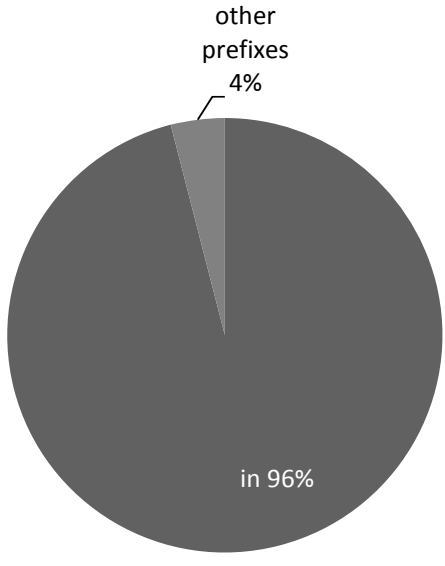

Italian

Figure 13. The English in and its French and Italian equivalents.

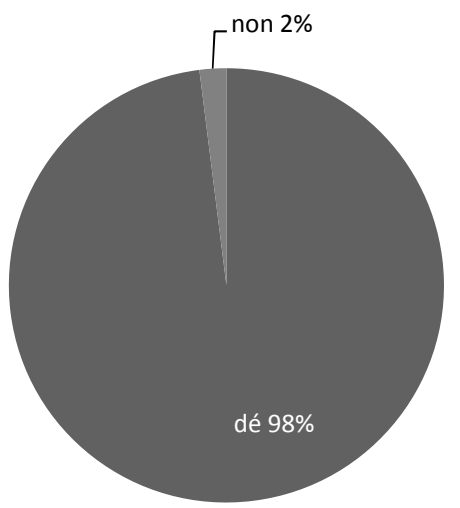

French

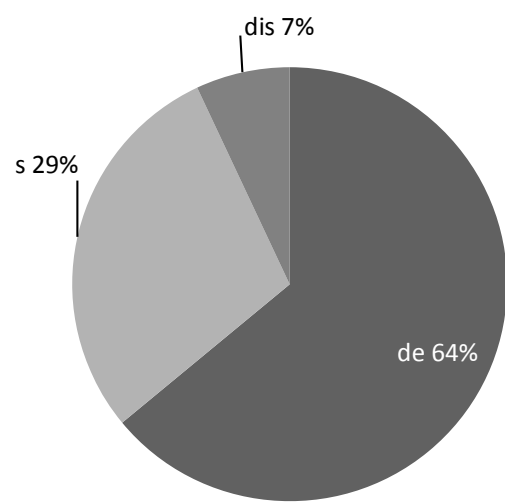

Italian

Figure 14: The English de and its French and Italian equivalents. 
sative prefixes are used in Italian, viz. de (63\%), $s(30 \%)$ and dis $(7 \%)$, as shown in Figure 14. This tends to confirm that Italian has a wider array of rever$\mathrm{sal} /$ removal prefixes at its disposal than French. In this respect, Italian is closer to English.

A similar discrepancy between Italian and French is observed in the translation patterns of the English dis, which may convey the meanings of rever$\mathrm{sal} / \mathrm{removal}$ and contrary negation. The French translations of this prefix include dé (84\% of the morphological translations) and in (7\%). Italian favours dis $(58 \%), s(26 \%)$, in (7\%) and $d e(7 \%)$, as shown in Figure 15. Once again, Italian appears to have more reversal/removal prefixes at its disposal than French. This apparent cross-linguistic contrast will have to be tested in an Italian-French bilingual corpus where both Italian and French act as source and target languages, as the trends presented here may be biased to some extent (Italian and French both act as target languages).

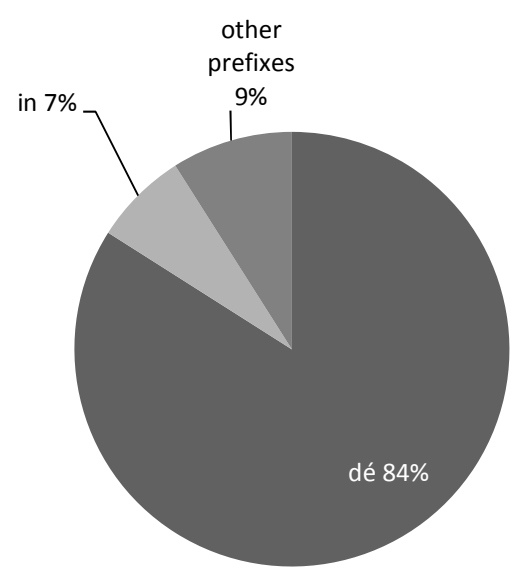

French

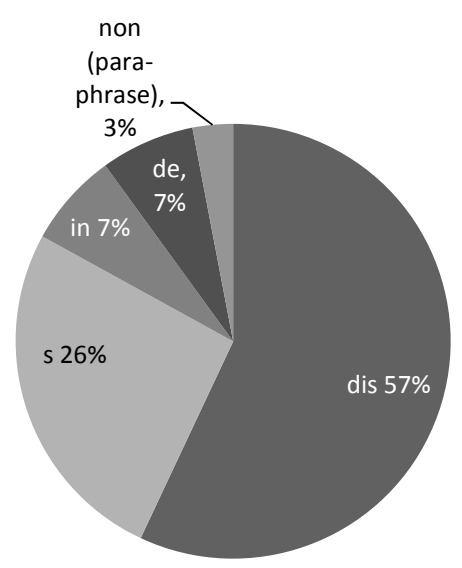

Italian

Figure 15. The English dis and its French and Italian equivalents.

The translation data also indicate that the prefix non is treated differently in the Italian and French translations. The major discrepancy is observed when non is used to coin a noun from a nominal base (e.g. non-taxation). In many cases, it is 
translated into French with a similar derivative (e.g. non-imposition), whereas the Italian translators show a marked preference for paraphrases containing mancato (e.g. mancata imposizione). Although still unaccounted for at this stage, this cross-linguistic pattern (associated with the other translations of non) points to a diverging use of non in the three languages investigated. More generally, our findings regarding the French/Italian contrasts show that the systematic examination of one source language and two target languages can bring to light some of the dissimilarities between the two target languages.

The results further show that translation data can be used to disambiguate polysemous affixes. In the case of un, for example, it appears that the reversal and removal meaning (mainly translated into dé in French and $s$ in Italian) is marginal compared to the contrary and contradictory meanings (translated into French and Italian in and non), which represent between $85 \%$ and $92 \%$ of the morphological translations of un (see Figure 16).

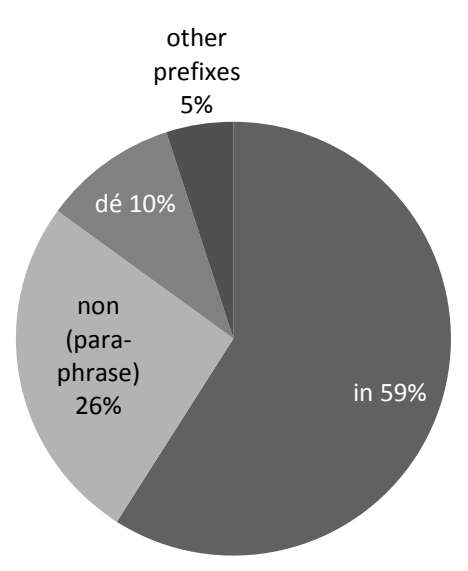

French

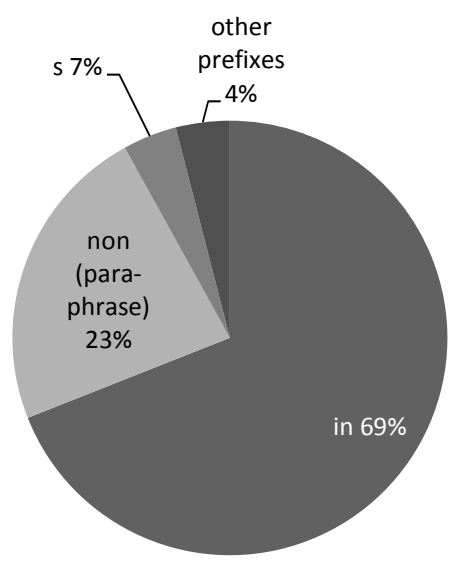

Italian

Figure 16. The English un and its French and Italian equivalents.

7. Concluding remarks and avenues for future research

The exploratory study presented in this paper has opened up many avenues for future research. As in most corpus-based investigations, large amounts of data 
were generated and follow-up studies clearly need to be carried out to further explore the many facets of negative morphology that were broadly sketched here.

First, our trilingual study needs to be replicated using other translation corpora (preferably representative of other registers, genres and domains) so as to confirm (or infirm) the contrastive trends presented here. It should be noted, however, that very few trilingual translation corpora have been compiled to date. In any case, other translation directions can be investigated on the basis of the Europarl corpus to complement the findings presented in this paper. This would make it possible to compute the mutual correspondence of affixes across languages (Altenberg 1999).

Second, a worthy area of investigation would be the in-depth study of paraphrases. The idea would be to start off from all the paraphrase patterns observed in the translated data in Italian and French and classify them semantically (contrary, contradiction, reversal, removal and privation). This categorisation would then enable us to pinpoint the semantic nuances of the English source affixes (de, dis, in, non, un, less), thereby refining the semantic characterisations found in the literature, which are still patchy. Third, the prefix non would also be worth investigating in more detail. Its status as a prefix is highly controversial in Italian and French when it is used in front of adjectives and the hyphenation patterns appear to be quite arbitrary. Finally, an insightful area of study would concern morphological phenomena that are not formally marked, such as conversion, which can be used to convey the negative sub-meanings of reversal and removal in English, and which therefore cannot be extracted by means of formbased queries.

Despite the work that remains to be done in this area, the exploratory results presented in this paper will hopefully have contributed to furthering the understanding of the intricacies involved in negative morphology in English, French and Italian and showed the benefits of translation corpus data in contrastive word-formation studies.

\section{Acknowledgments}

* The first author gratefully acknowledges the financial support of the Swiss National Science Foundation (SNSF, COMTIS Sinergia project). We also wish to thank the anonymous reviewers for their insightful comments on the first draft of this paper. 


\section{REFERENCES}

Algeo, J. 1971. "The voguish uses of non". American Speech 46(1-2). 87-105.

Altenberg, B. 1999. "Adverbial connectors in English and Swedish: Semantic and lexical correspondences”. In: Hasselgård, H. and S. Oksefjell (eds.), Out of corpora. Studies in honour of Stig Johansson. Amsterdam: Rodopi. 249-268.

Amiot, D. 2008. "La catégorie de la base dans la préfixation en dé-". In: Fradin, B. (ed.), La raison morphologique: Hommage à la mémoire de Danielle Corbin. Amsterdam: John Benjamins. 1-16.

Anscombre, J.-C. 1994. "L'insoutenable légèreté morphologique du préfixe négatif indans la formation d'adjectifs". Linx. 299-321.

Apothéloz, D. 2003. "Le rôle de l'iconicité constructionnelle dans le fonctionnement du préfixe in-". Cahiers de linguistique analogique 1. 35-63.

Baayen, R. H. 1992. "Quantitative aspects of morphological productivity”. In: Booij, G. and J. Van Marle (eds.), Yearbook of morphology 1991. Dordrecht: Kluwer. 109149.

Baker, M. 1993. "Corpus linguistic and translation studies: Implications and applications”. In: Baker, M., G. Francis and E. Tognini-Bonelli (eds.), Text and technology. In honour of John Sinclair. Amsterdam: John Benjamins. 233-250.

Barlow, M. 2008. "Parallel texts and corpus-based contrastive analysis". In: de los Ángeles Gómez González, M., J. Lachlan Mackenzie and E. M. González Álvarez (eds.), Current trends in contrastive linguistics. Functional and cognitive perspectives. Amsterdam: John Benjamins. 101-121.

Bauer, L. 1983. English word-formation. Cambridge: Cambridge University Press.

Bertrand, C. 1986. "Quelques remarques sur les adverbes français en -ment et leur rapport avec les adverbes anglais en -ly". Meta 31(2). 179-203.

Boons, J.-P. 1984. "Sceller un piton dans le mur ; desceller un piton du mur. Pour une syntaxe de la préfixation négative". Langue Française 62. 95-128.

Cartoni, B. and M.-A. Lefer. 2010. "Improving the representation of word-formation in multilingual lexicographic tools: The MuLeXFoR database". In: Dykstra, A. and T. Schoonheim (eds.), Proceedings of the XIV Euralex International Congress. Leeuwarden: Fryske Academy. 581-591.

Chuquet, H. and M. Paillard. 1987. Approche linguistique des problèmes de traduction anglais-français. Paris: Ophrys.

Dal, G., N. Grabar, S. Lignon, D. Tribout and F. Yvon. 2007. "Les adjectifs en inXable du français". In Florilic, F. (ed.), La négation dans les langues romanes. Amsterdam: Benjamins. 215-234.

Dardano, M. 1978. La formazione delle parole nell 'italiano di oggi. Roma: Bulzoni editore.

Fløttum, K., T. Dahl and T. Kinn. 2006 Academic voices - Across languages and disciplines. Amsterdam: Benjamins.

Funk, W.-P. 1971. "Adjectives with negative affixes in Modern English and the problem of synonymy”. Zeitschrift für Anglistik und Amerikanistik 19(4). 364-386. 
Gaatone, D. 1971. Étude descriptive du système de la négation en français contemporain. Genève: Librairie Droz.

Gary-Prieur, M.-N. 1976. "Déboiser et déboutonner : Remarques sur la construction de sens des verbes dérivés par dé-". In: Chevalier, J.-C. (ed.), Grammaire transformationnelle: Syntaxe et lexique. Villeneuve d'Ascq: Publications de l'Université de Lille III. 95-138.

Gellerstam, M. 1996. "Translations as a source for cross-linguistic studies". In: Aijmer, K., B. Altenberg and M. Johansson (eds.), Languages in contrast. Papers from a symposium on text-based cross-linguistic studies, Lund, 4-5 March 1994. Lund: Lund University Press. 53-62.

Gerhard, F. 1998. "Le préfixe dé-, dés- : Privation ou inversion ? Le cas des verbes préfixés dont la base réfère à une partie d'un tout". Orbis Linguarum 9. 189-200.

Grevisse, M. 1993. Le bon usage. (13th ed., revised by A. Goosse.) Paris and Louvainla-Neuve: De Boeck-Duculot.

Guilbert, L. 1971. "De la formation des unités lexicales". In: Grand Larousse de la langue française. Paris: Larousse. IX-LXXXI.

Granger, S. 2003. "The corpus approach: A common way forward for contrastive linguistics and translation studies?" In: Granger, S., J. Lerot and S. Petch-Tyson (eds.), Corpus-based approaches to contrastive linguistics and translation studies. Amsterdam: Rodopi. 17-29.

Hamawand, Z. 2009. The semantics of English negative prefixes. London: Equinox.

Heuzinger, K. von and C. Schwarze. 2006. "Underspecification in the semantics of word-formation: The case of denominal verbs of removal in Italian". Linguistics 44(6). 1165-1194.

Huet, S., J. Bourdaillet and L. Langlais. 2009. "Intégration de l'alignement de mots dans le concordancier bilingue TransSearch". In: Proceedings of TALN'09. Senlis, France.

Huot, H. 2007. "La préfixation négative en français moderne". In: Florilic, F. (ed.), La négation dans les langues romanes. Amsterdam: Benjamins. 177-204.

Iacobini, C. 2004. "I prefissi”. In: Grossmann, M. and F. Rainer. (eds.), La formazione delle parole in italiano. Tübingen: Niemeyer. 99-163.

James, C. 1980. Contrastive analysis. Harlow: Longman.

Johansson, S. 2003. "Contrastive linguistics and corpora”. In Granger, S., J. Lerot and S. Petch-Tyson. (ed.), Corpus-based approaches to contrastive linguistics and translation studies. Amsterdam: Rodopi. 31-44.

Johansson, S. 2007. Seeing through multilingual corpora. On the use of corpora in contrastive studies. Amsterdam: Benjamins.

Koehn, P. 2005. "Europarl: A parallel corpus for statistical machine translation". MT Summit 2005.

Krzeszowski, T. 1990. Contrasting languages. The scope of contrastive linguistics. Berlin: Mouton de Gruyter.

Laviosa, S. 2002. Corpus-based translation studies: Theory, findings, applications. Amsterdam: Rodopi. 
Lefer, M.-A. and B. Cartoni. 2011. "Prefixes in contrast: Towards a meaning-based contrastive methodology for lexical morphology”. Languages in Contrast 11(1). 86104.

Lieber, R. 2004. Morphology and lexical semantics. Cambridge: Cambridge University Press.

Lieber, R. 2005. "English word-formation processes. Observations, issues, and thoughts on future research". In: Štekauer, P. and R. Lieber (eds.), Handbook of wordformation. Dordrecht: Springer. 375-427.

Lyons, J. 1968. Introduction to theoretical linguistics. Cambridge: Cambridge University Press.

Montermini, F. 2002. Le système préfixal en italien contemporain. ( $\mathrm{PhD}$ dissertation, Université de Paris X-Nanterre, Università degli Studi di Bologna.)

Muller, C. 1990. "Contraintes de perception sur la productivité de la préfixation verbale en dé- négatif". Travaux de Linguistique et de Philologie 28. 173-192.

Namer, F. and E. Jacquet. 2003. "Lexical semantics and derivational morphology: The case of the popular 'é-' prefixation in French". GL 2003: 2nd International Workshop on Generative Approaches to the Lexicon, 15-17 May 2003, Geneva. 115122.

Paillard, M. 2000. Lexicologie contrastive anglais-français : Formation des mots et construction du sens. Paris: Ophrys.

Plag, I. 2003. Word-formation in English. Cambridge: Cambridge University Press.

Scalise, S. and A. Bisetto. 2008. La struttura delle parole. Bologna: Il Mulino.

Schwarze, C. 2004. "Compositionnalité et variation sémantique en morphologie lexicale". Verbum 26(4). 481-501.

Schwarze, C. 2005. "Grammatical and paragrammatical word-formation". Lingue e Linguaggio 4(2). 137-162.

Tranel, B. 1976. "A generative treatment of the prefix in- of Modern French". Language 52(2). 345-369.

Zimmer, K.E. 1964. "Affixal negation in English and other languages: An investigation of restricted productivity". Supplement to Word 20(2).

\title{
DICTIONARIES
}

[DISC] Sabatini, F. and V. Coletti (eds.). 2003. Il Sabatini Coletti. Dizionario della Lingua Italiana. Milan: Rizzoli Larousse.

Imbs, P. and B. Quemada (ed.). 2004. Le Trésor de la Langue Française informatisé. Paris: CNRS Editions and Université Nancy-II. <http://atilf.atilf.fr/tlf.htm>.

\author{
Address correspondence to: \\ Bruno Cartoni \\ Département de Linguistique \\ Université de Genève \\ 5 rue de Candolle \\ 1211 Genève 3 , Switzerland \\ bruno.cartoni@unige.ch
}

